\title{
Interaction of Environmental Pollutants with Microplastics: A Critical Review of Sorption Factors, Bioaccumulation and Ecotoxicological Effects
}

\author{
Albert Menéndez-Pedriza and Joaquim Jaumot * \\ Department of Environmental Chemistry, IDAEA-CSIC, Jordi Girona 18-26, 08034 Barcelona, Spain; \\ ampqam@idaea.csic.es \\ * Correspondence: joaquim.jaumot@idaea.csic.es
}

Received: 23 April 2020; Accepted: 29 May 2020; Published: 2 June 2020

\begin{abstract}
Microplastics have become one of the leading environmental threats due to their persistence, ubiquity and intrinsic toxic potential. The potential harm that microplastics impose on ecosystems varies from direct effects (i.e., entanglement and ingestion) to their ability to sorb a diversity of environmental pollutants (e.g., heavy metals, persistent organic compounds or pharmaceuticals). Therefore, the toxicological assessment of the combined effects of microplastics and sorbed pollutants can produce in biota is one of the hottest topics on the environmental toxicology field. This review aims to clarify the main impacts that this interaction could have on ecosystems by (1) highlighting the principal factors that influence the microplastics sorption capacities; (2) discussing the potential scenarios in which microplastics may have an essential role on the bioaccumulation and transfer of chemicals; and (3) reviewing the recently published studies describing toxicological effects caused by the combination of microplastics and their sorbed chemicals. Finally, a discussion regarding the need for a new generation of toxicological studies is presented.
\end{abstract}

Keywords: microplastics; environmental pollutants; sorption; bioaccumulation; toxicological studies

\section{Introduction}

The term plastic is a generic name encompassing most of the synthetic and semisynthetic organic polymers which are capable of exhibit plasticity. These materials are ideal for a large variety of applications due to their versatility, durability, lightweight, chemically inert behaviour and their low-cost-production, among others. All these outstanding features could explain why global plastic production has increased significantly over the past decades (1.7 million tons in the 1950s to 359 million tons in 2018, Figure 1a) [1]. Moreover, experts believe that consumer needs will not decline in the near future. Consequently, by 2050, the world's plastic production is estimated to exceed the 1000 million metric tons per year. Although the societal benefits of plastic materials are indubitable, the poor management in plastic debris through the last decades has led plastics to currently become one of the largest portions of the municipal waste. Until the year 2017, estimates stated that approximately 6300 million tons of plastic waste had been generated globally. From this huge amount, only twenty per cent of this litter was recycled or incinerated. In contrast, the remaining eighty per cent was either accumulated in landfills or released to natural environments (e.g., marine and freshwater ecosystems) [2]. These estimates also affirmed that around ten per cent of the plastic produced over the years had been discharged in the marine environment. All these factors lead to the fact that plastic debris already encompasses for sixty to eighty per cent of the marine litter, after less than a century of existence [3]. Unfortunately, these effects could be aggravating in the near future as estimates indicate that roughly eight million tons of plastic materials end up in the marine environment every year [4]. 
Hence, plastic marine litter has become a global environmental menace due to its persistence, ubiquity and toxic potential. Recent studies have also raised concerns on the ability of microplastics (MPs) to sorb on their surface a vast number of environmental compounds (e.g., heavy metals, persistent organic compounds (POPs), pharmaceuticals) [5-8]. Thus, considering the new shreds of evidence on the multiple risks that plastics pose to the environment, different marine protection projects such as the Marine Debris Program of the US National Oceanographic and Atmospheric Administration (NOAA), included plastics litter as an emerging pollutant [9]. Therefore, the evaluation of the possible ecological impacts of plastic waste in marine ecosystems has currently become one of the key research fields for the scientific community, highlighting the particular attention posed on small pieces of plastic, referred to as MPs.

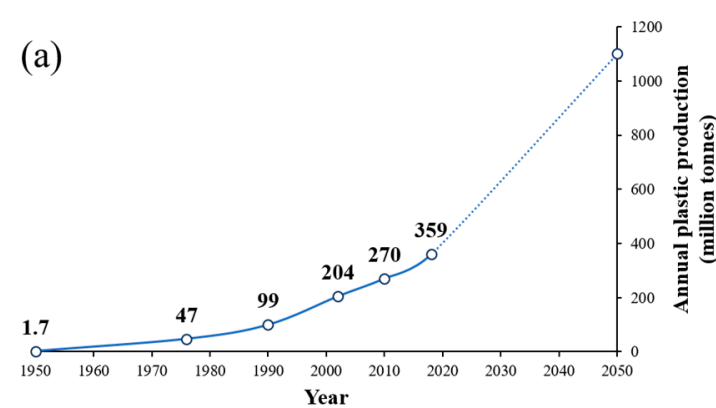

(b)
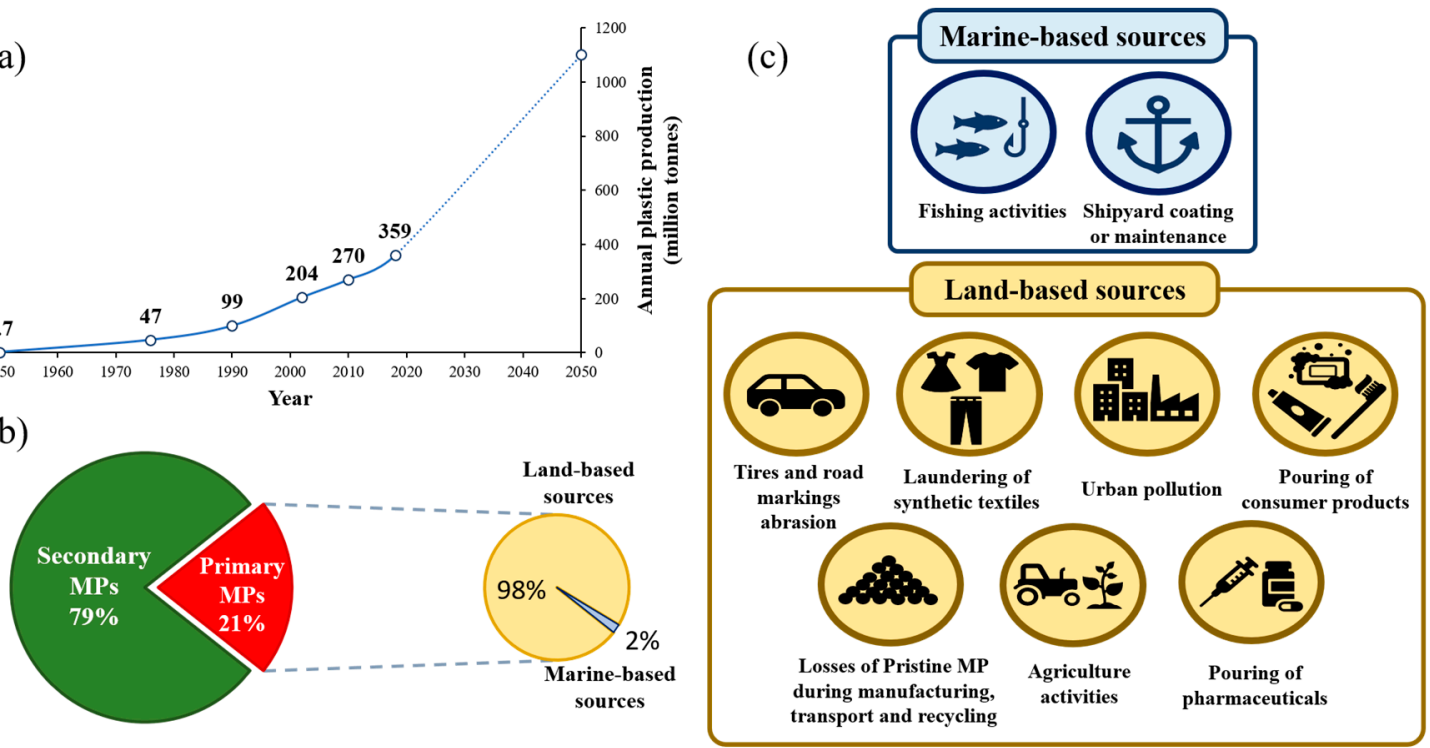

Figure 1. (a) Global plastic production since the 1950s together with an estimate of the global plastic production until 2050. (b) Estimated percentage of primary microplastics (MPs) that ends up into oceans respect the total MPs materials released into marine ecosystems every year. The percentage of land-based and marine-based contributions are also presented. (c) Most important land-based and marine-based sources of primary MPs released into marine ecosystems.

Small pieces of floating plastics in the ocean surface were firstly reported in the scientific literature in the early 1970s. However, the NOAA did not define MPs as synthetic polymers with an upper size limit of $5 \mathrm{~mm}$ until 2009 [10]. MPs are divided into large $(1-5 \mathrm{~mm})$ and small $(1-1000 \mu \mathrm{m})$. Larger plastics were categorized as megaplastics (larger than $1000 \mathrm{~mm}$ ), macroplastics (from 250 to $1000 \mathrm{~mm}$ ) and mesoplastics (from 5 to $250 \mathrm{~mm}$ ). Below the $1 \mu \mathrm{m}$ scale, plastics should be designated as nanoplastics (NPs), another rather unknown part of the marine waste. These NPs may also represent a risk in the environment due to their sizeable amount, but in-depth studies are required to understand their toxic effects and mechanisms.

MPs can be classified into primary and secondary MPs. Primary MPs are manufactured plastics for industrial or domestic use of microscopic scale. Virgin or pristine plastic pellets are also considered as primary MPs. There are several applications of these primary MPs in various industries [11,12] such as cosmetics (i.e., facial cleansers, toothpaste or shower gels), textile (i.e., stockings, faux leather, fur or suits) and medical applications (i.e., vectors for drugs). Besides, the large amounts of primary MPs generated in the car tires abrasion while driving and the laundering of synthetic textiles make them the main sources of generation of this type of MPs. Therefore, land-based activities produce almost all the losses of primary MPs (Figure 1b) [13]. However, these primary MPs commonly end up in either fresh-water or seawater environments through different pathways such as wind transfer, 
discharge from wastewater plants systems, road runoff and industrial or domestic drainage. All these contributions result in an estimated global release of between 0.8 and 2.5 Mtons of primary MPs into the marine environment every year according to an optimistic or pessimistic scenario, respectively (Figure 1b) [13]. The following example is introduced to highlight this contribution. Considering a release of 1.53 Mtons/year of primary MPs, 43 light plastic bags should be thrown into oceans per person each week. Consequently, the proportion of primary MPs represent between $15 \%$ and $31 \%$ of the total MPs in the oceans according to the study by Boucher [13].

The plastic waste in the land and oceans can be further fragmented into much smaller particles due to degradation processes, which are more reactive and dangerous to marine fauna and humans. These MPs are known as secondary MPs and present a variety of origins, including fishing nets, industrial resin pellets, household items, and other discarded plastic debris [12]. A variety of environmental and mechanical factors control plastics fragmentation rates. Therefore, these environmentally-linked degradation processes can be classified as biodegradation (i.e., the action of living organisms), photodegradation (i.e., light radiation), thermo-oxidative degradation (i.e., slow oxidative breakdown at moderate temperature), thermal degradation (i.e., high temperature) and hydrolysis (i.e., water) [14]. It is established that land-based sources contribute to the formation of more than eighty per cent of the total microplastic debris in the marine environment [11]. This fact might be explained because these main degradation processes are more effective in land-based sources than in the aquatic environment. For instance, the UV radiation degradation mechanism (which commonly starts with a photooxidative degradation step) is more effective in plastics exposed in land-based sources (e.g., beaches). Photodegradation is also less efficient when the plastic material is floating in the water. The low temperature and oxygen concentrations in the aquatic environment may explain this decrease in the degradation efficiency [14]. However, the complete understanding of these degradation processes needs to combine the effects of several environmental factors and properties of the plastic polymers.

Due to the action of different natural processes such as infiltration, river discharge, wind, ocean currents, and the movement of animals and humans within and between ecosystems, MPs are in almost every habitat around the world (even in the polar regions [15]). In the aquatic ecosystems, MPs are present in every state of the water column (i.e., from surface waters to benthic zones). The nature and inherent properties of MPs (like shape, density or size) significantly influence their distribution, as well as the localization of the MPs sources and their subsequent complex interaction between physical, chemical and biological processes.

Currently, there is growing information about all these aspects related to the MPs effects on the environment. Many studies deal with the abundance and composition of MPs [16-18], but major uncertainties remain regarding the spatial and temporal distribution of MPs. Temporal variations and the lack of standardized analytical methods may be the main factors that explain this fact.

The MPs threat on ecosystems, marine organisms or humans due to their persistence and ubiquity explains the growing interest of the scientific community in this type of plastic debris [19]. These MPs' environmental impacts can be classified in physical, biological and chemical effects.

Physical impacts include the entanglement and the ingestion of MPs, with entanglement being the most common, particularly for larger plastics (macroplastics and mesoplastics). However, the impacts of MPs on small-sized animals have been recently described in the literature. For instance, the entanglement of MPs to the swimming appendages of mysids was observed in the work of Lehtimieni [20]. Besides, large filter-feeding marine organisms may potentially ingest huge amounts of MPs due during feeding intervals. This phenomenon is especially significant in areas where zooplankton blooms concur with a higher accumulation of MPs (e.g., coastlines, thermal currents or ocean gyres such as the North Pacific central gyre) [21,22].

Ingestion of plastics can be direct or indirect. Direct ingestion occurs when animals eat them accidentally. In contrast, indirect ingestion is related to the trophic transfer being the result of the consumption of contaminated food. Several works document the ingestion of MPs at every trophic 
level, including zooplankton [23-25], mussels [26,27], fishes [25,28-31], sea turtles [32] and marine birds [25,33-35]. These physical impacts may induce drowning, suffocation, strangulation, and starvation [36] in addition to the damage to gills and other internal organs. Additionally, other effects such as reduction of the predatory performance, changes in the metabolism or the endocrine function, and other adverse effects potentially leading to death have also been reported [37-41]. Consequently, the lethal physical impact of plastic materials by marine animals has increased by almost $40 \%$ in the last decade, according to the Convention on Biological Diversity report [36].

Biological effects are caused by the changes in MPs physical properties due to the attachment of biofilms on their surface. Biofilms are phylogenetically and functionally diverse communities of bacteria, protozoans, algae, and fungi collectively forming a microbial assemblage, biofouling community, or periphyton [42]. Nowadays, the influence of such biofilms on the fate and potential effects of MPs is not well understood, and further investigation is needed [42,43]. Moreover, biological impacts also include the capacity to transfer microorganisms geographically.

Finally, the chemical impact of MPs might be attributed to residual monomers from manufacture present in the plastic. Furthermore, plastics may incorporate some chemical additives added during their production to improve physical properties such as colour, density, resistance or hardness. Many of these additives induce relevant ecotoxicological effects on humans and marine organisms. Examples of these additives are Bisphenol A (BPA) [44,45] (i.e., provides antioxidant properties to the plastic even though it is mainly found in the environment as a residual compound during the synthesis of polycarbonates and epoxy resins), several common-used flame retardants [46,47] and antimicrobial agents. [48]. Besides, the toxicity of some intermediates from partial degradation of plastics should also be considered [14]. However, recent studies have raised concerns on chemical effects due to the ability of MPs to sorb on their surface environmental pollutants. Examples of compounds sorbed to MPs surface are heavy metals or highly hydrophobic contaminants like persistent organic pollutants (POPs), including polychlorinated biphenyl (PCBs), polybrominated diphenyl ethers (PBDEs), dichlorobiphenyl trichloroethane (DDTs), hexachlorocyclohexanes (HCHs) and polycyclic aromatic hydrocarbon (PAHs) [49-54]. These studies pointed out a substantial enrichment of POPs in the polymers, often exceeding $10^{6}$ times relative to their concentrations in solution [55]. Similarly, the potential interaction of MPs with other emerging pollutants such as pharmaceuticals active compounds (PhACs), antibiotics, or UV filters have also raised the interest of the scientific community [56-58].

Therefore, MPs may play a crucial role in aquatic ecotoxicology acting as vectors for these highly toxic pollutants, becoming a potential source of lipophilic chemicals for bioaccumulation and biomagnification by facilitating their entrance to the food chain [59]. For that reason, several studies have assessed the potential bioaccumulation and bioavailability enhancement of chemicals previously sorbed on MPs [60-64]. Conversely, many authors have refuted the idea that MPs might have a relevant role in this bioaccumulation and biomagnification of toxic chemicals like POPs by marine animals. These works argue that plastic debris present in the oceans is still not enough to outcompete the partitioning of POPs to water and dissolved organic matter (DOM) $[55,65,66]$. Moreover, they highlight the unrealistic high concentrations used during most of the experiments, in addition to the incomparable sampling and analytical methods applied. For these reasons, the influence in the transport and bioaccumulation of pollutants by plastics is a current topic of debate within the scientific community. In the last years, several toxicological studies about MPs focused on the ecotoxicological assessment of their combined effects with environmental pollutants in diverse aquatic animals along with the food web. These studies are crucial to better understand the possible existence of interactions between plastic debris and these environmental pollutants as well as to assess the real toxicological impact that MPs have in the marine ecosystems.

To date, reviews on the behaviour of MPs in the environment have focused on summarizing their properties, sources, fate and occurrence $[11,14,67]$, instrumental methods for their analysis $[4,68]$, biological effects on organisms [19,36,69-71] and their chemical sorption capacities [72-76]. Nonetheless, the discussion about if MPs may act as a vector for POPs and other environmental 
pollutants, like heavy metals and pharmaceuticals, is still active. However, there is a lack of critical evaluation of the current research trends related to ecotoxicological effects assessed by the MPs chemical interaction in aquatic animals. Thus, this review aims to (i) describe the main factors influencing the sorption properties of plastics; (ii) present the different scenarios in which MPs may have an impact on the transfer and bioaccumulation of chemicals; and (iii) summarize the main ecotoxicological effects of MPs combined with sorbed environmental pollutants.

\section{Factors Influencing the Sorption of Environmental Pollutants to MPs}

The process of chemical transfer from a fluid phase (e.g., air or water) to a solid phase (e.g., plastic debris or DOM) defines the sorption of a compound. This term is associated with two types of processes: absorption and adsorption. The term absorption refers to the chemical interaction between compounds and a sorbent through relatively weak van-der-Waals forces in which molecules penetrate and become embedded within the matrix sorbent. In this phenomenon, the resulting partition coefficient $\left(\mathrm{K}_{\mathrm{pw}}\right)$ between plastic and water can be related to the octanol-to-water partition ratio $\left(\mathrm{K}_{\mathrm{ow}}\right)$ of polymers, in particular for the case of polyolefins [73,77]. In contrast, the term adsorption involves a variety of forces, from van-der-Waals to ionic, steric or covalent interactions. In these chemical processes, molecules remain in the interface between the fluid and the solid surface. In many cases, both absorption and adsorption processes may arise concurrently, so it is difficult to discriminate one interaction from the other [72]. However, adsorption processes predominate in the most usual scenario of low environmental concentrations of organic chemicals due to the stronger interactions with the solid phase surface. Otherwise, at higher concentrations, absorption is more likely to occur due to the larger amount of available compounds [74].

Finally, it should be highlighted that these sorption processes are fundamentally related to the physicochemical properties of both the sorbate and the sorbent as well as the medium properties. Therefore, the sorption mechanisms between an organic pollutant and MPs depend on the interactions between them, which can be dominated by a specific contribution or even be a composed of several types of contributions. The most important factors to understand the pollutant-plastic interactions are graphically summarized in Figure 2 and will be described below.

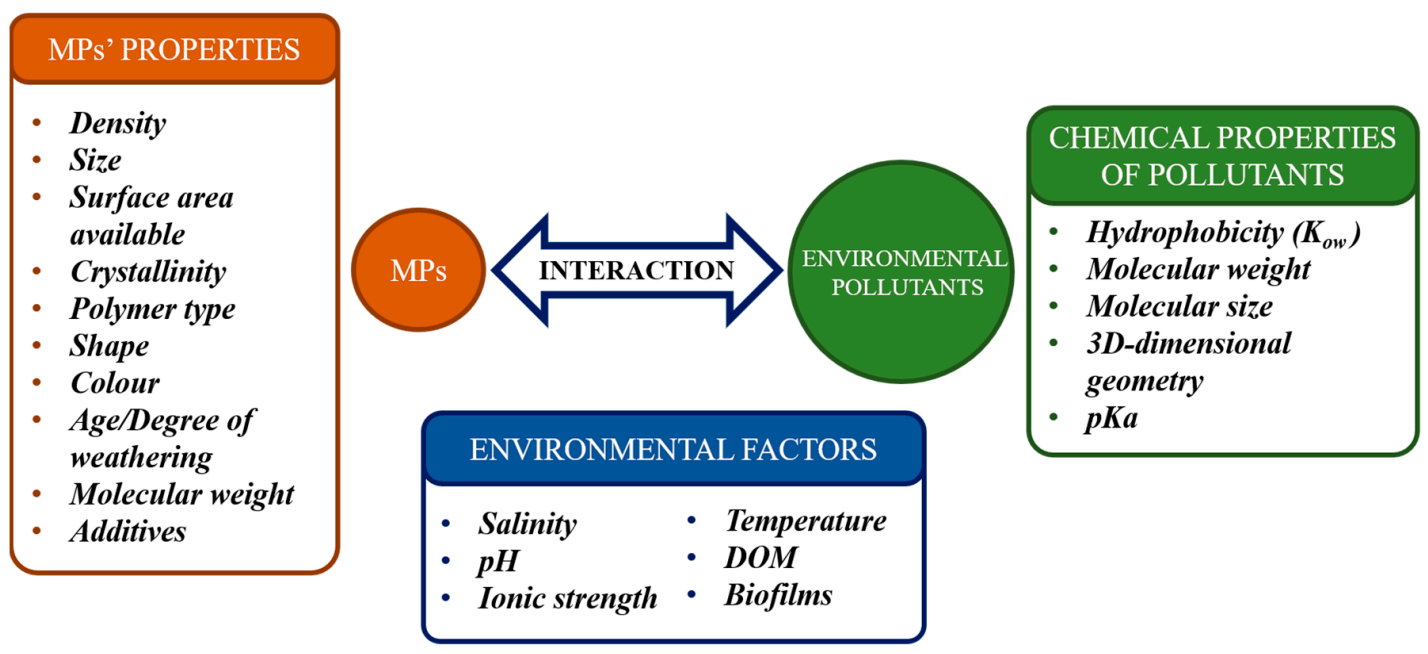

Figure 2. Summary of the main factors influencing the interaction between MPs and chemical pollutants.

\subsection{Plastic Polymer Type}

The inherent structural properties of a polymer (i.e., surface charge and area, molecular chain arrangement or acid-base character) are responsible for its fate. These attributes influence the sorption processes and the type of organic pollutants sorbed on the surface of the plastic particle. One of the most important plastic features affecting sorption processes is the degree of polymer crystallinity, 
which is related to the molecular chain arrangement. Polymers are composed both by crystalline and amorphous regions. Molecular segments showing a regular structure form the crystalline region, whereas areas with randomly packed chains constitute the amorphous region. In the structured domain, a high amount of energy is needed for the process of chemicals absorption. In contrast, random regions have a larger extent of free volume because of the distance between polymeric chains, which allows chemicals to diffuse more easily through the polymer. As a result of the size and complexity of these chains, polymers can only be semi-crystalline, mixing crystalline and amorphous regions, or completely amorphous [72]. Some examples of semi-crystalline polymers are polyethylene (PE), polypropylene (PP), polyethylene terephthalate (PET) and polytetrafluoroethylene (PTFE). Several factors affect polymer crystallinity, including polymer complexity, chain configuration, isomerism and rate of cooling during solidification.

Another major characteristic to take into account is the glass transition temperature $\left(T_{g}\right)$, which is only related to the amorphous domains of the polymer. At temperatures below $\mathrm{T}_{\mathrm{g}}$, the amorphous segments are in the glassy state, and above $\mathrm{T}_{\mathrm{g}}$, they are in the rubbery state. It is crucial to mention that rubbery polymers (e.g., PE and PP) have higher diffusivity due to their larger free volume and their greater flexibility and mobility. Hence, these properties enhance the absorption of organic pollutants in these regions. The sorption isotherms of this type of polymers are essentially linear (i.e., Henry isotherm model, Figure 3), and the absorption process is reversible and non-competitive [78].

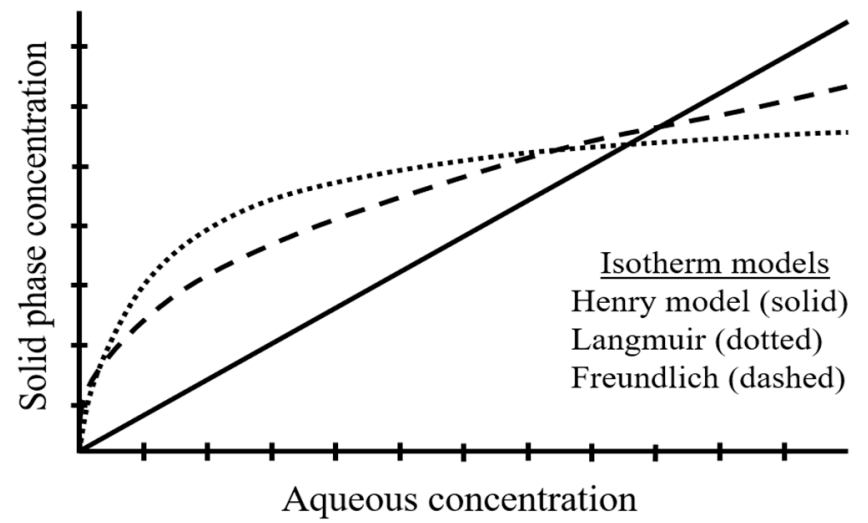

Figure 3. Standard isotherm models used in the study of sorption/desorption of environmental pollutants in MPs.

Conversely, glassy polymers (e.g., PS, PET and polyvinyl chloride (PVC)) are more condensed and present higher cohesive forces. Thereupon, this kind of polymers have long-lived and closed internal nanoscale pores which act as adsorption sites. For that reason, glassy polymers are responsible for lower release rates, as this trait creates stronger adsorption sites to organic compounds [74]. Consequently, adsorption processes may be the predominant sorption mechanism for glassy polymers [53]. Adsorption processes can be described applying several nonlinear isotherms (i.e., Langmuir and Freundlich nonlinear isotherm models, which are the most commonly used, Figure 3) and show competition mechanisms with any coexisting chemical [54,79]. Despite that, it must be considered that both absorption and adsorption processes may arise concurrently. Therefore, as pointed out in different studies, the Freundlich model is widely used to describe the pollutants-MPs interaction as enables a proper fitting of the results for many sorption/desorption processes [80-82].

Previous studies reported PE as the polymer, which sorbs and concentrates the highest amount of organic pollutants in comparison to PP and PVC [51,52,54]. Consequently, the order in the sorption capability of the most common plastic types has been determined by the following list: $\mathrm{LDPE} \approx \mathrm{HDPE}>\mathrm{PP}>\mathrm{PVC} \approx \mathrm{PS}$ [83]. PVC and PS are glassy polymers resulting in low mobility and low diffusivity of the sorbate. Despite that, other polymer characteristics can overrule the crystallinity effect, making its influence negligible. For example, Rochman et al. [50] reported that PS (glassy 
polymer) presents similar sorption capacities than LDPE and HDPE (rubbery polymers) for different PAHs. In this case, the authors argued that the greater segmental mobility of PE was compensated by the greater distance between polymeric chains in PS. Moreover, PS could undergo $\pi-\pi$ interactions. Similar conclusions were reached by Seidensticker et al. (2018) [84]. This work demonstrated that the larger porous size of PS compared to PE enables a major sorption capacity of PS respect PE. Hence, these observations imply that the structural characteristics of each polymer have a profound influence on the sorption capacities of organic chemicals by plastics.

\subsection{Size of the Plastic Pellets}

Particle size is another relevant plastic property to understand the MPs-chemicals interaction since the sorption capacity is inversely proportional to the particle size (i.e., decreased particle size increases the surface area to volume ratio). For this reason, different authors underline their potential "Trojan horse" effect (i.e., hiding of the actual toxic potential of MPs and NPs due to their ability of sorbing multiple harmful pollutants) $[8,60,85]$. When sorption between MPs and NPs are compared, the sorption rates for NPs are one or two orders of magnitude higher [74]. However, this plastic size mainly affects adsorption rather than absorption, as the second does not depend on the availability of sorption sites on the surface [49]. This behaviour causes that authors need to be cautious regarding the influence of the particle size if the absorption process and other polymer features are involved. For instance, Hüffer and Hoffman [53] could not explain the sorption differences of a variety of organic chemicals with polyamide (PA), PE, PS and PVC considering only the MPs size effect and pointed out the considerable influence of hydrophobic interactions. It has to be also mentioned that we should also consider that the tendency for plastic particles to aggregate in the environment may lead to a reduction of the available surface area for chemical sorption. Consequently, particles' aggregation may significantly affect the sorption capacities of plastics.

Summarizing, the size effect of plastic particles seems a matter of concern as smaller particles may represent a higher hazardous risk to the marine environment due to their increased potential to preconcentrate organic pollutants. Moreover, it also seems relevant to consider the actual size range distribution of plastic debris in the marine environment. In addition, the significance of processes involving MPs and NPs may vary depending on their relative abundance in the environment, and this could also influence the exposure perspective of the ecotoxicological studies evaluating their toxic potential.

\subsection{Age and Degree of Weathering of Plastic}

Pristine or virgin plastics are the newly manufactured and have not suffered any degradation by the environment. Conversely, aged or weathered plastics are those that have been exposed to degradation processes (i.e., thermal, mechanical, biological, radiative, oxidative breakdown or hydrolysis) [14,73]. The susceptibility to these environmental conditions enables the fragmentation and cracking of plastic debris into smaller particles. Therefore, an in-depth study of the degradation mechanisms of plastics caused by weathering, which facilitates the fragmentation of plastics into smaller-sized particles, is required.

Another important fact to point out is that aged pellets may also suffer chemical changes. For example, polymer crystallinity is susceptible to increase by weathering. For this reason, some authors considered that the sorption rates of organic pollutants by aged plastics might be reduced relative to the sorption rates of virgin plastics [86]. However, other studies reached opposite conclusions. For instance, Teuten et al. exposed that yellowing aged pellets had higher concentrations of PCBs [54]. Based on this finding, the International Pellet Watch project proposed a standardized methodology to monitor coastal pollution by hydrophobic chemicals [87]. They proposed analysing yellow pellets (i.e., the yellowing effect occurs as the result of phenolic oxidation agents to by-products with quinoidal structures that cause yellow colour), as these pellets tended to have higher concentrations of POPs. Results demonstrated the utility of weathered pellets to monitor POPs on a global scale. 
Accordingly, Chen et al. concluded that weathering enhanced the sorption capacity of different PAHs by MPs [88]. Other authors also confirmed that aged MPs lead to higher sorption capacities of POPs $[52,89,90]$. Chemical changes on aged plastics surface may also have significant relevance, as their surface can be oxidized, allowing the interaction with new hydrophilic organic compounds. Results noted by Huffer et al. pointed to this way, suggesting that the weathering process reduced the hydrophobicity of plastics due to the surface oxidation, which created new functional groups containing oxygen [91]. Similarly, Fu et al. reported that aged PVC micropellets were capable of sorbing higher amounts of copper due to surface changes induced by UV radiation [92]. Wang et al. revealed that the aged MPs had a higher adsorption capacity of heavy metals than pristine pellets. This fact was explained by the authors considering the correlation of the increased surface area and the oxygen-containing functional groups appeared in the surface of aged MPs after UV radiation [93]. Consequently, it seems that the functional groups and polarities of MPs significantly contribute to the accumulation of different types of pollutants from the environment.

Biological effects, for instance, the development of biofilms on the surface of plastic pellets, can also alter the polarity of these pellet surfaces as well as the specific surface-volume ratio [42]. Richard et al. concluded that biofilms enhanced the accumulation of various metals in plastic debris (e.g., Ga, Mn, $\mathrm{Pb}, \mathrm{Cu}, \mathrm{Co}, \mathrm{U}, \mathrm{Fe}, \mathrm{Ni}, \mathrm{Al}$ ) [43]. In addition, Johansen et al. demonstrated that the enhanced sorption of Cs and Sr onto PE and PP MPs was possible due to the increased surface area allowed by the biofilms action [94].

Finally, it should be mentioned that weathering effects might also enable the release of toxic plasticizers and additives (e.g., phthalates, alkylphenols). Therefore, the weathering or ageing effect can change the sorption capacity of organic pollutants through the following aspects as represented in Figure 4: (1) fragmentation of larger plastic debris increases the specific surface area; (2) modulation of polymers properties (e.g., crystallinity); (3) oxygen-containing functional groups change surface properties on MPs by decreasing their hydrophobicity; and (4) attached biofilms improve the sorption capacity of MPs.

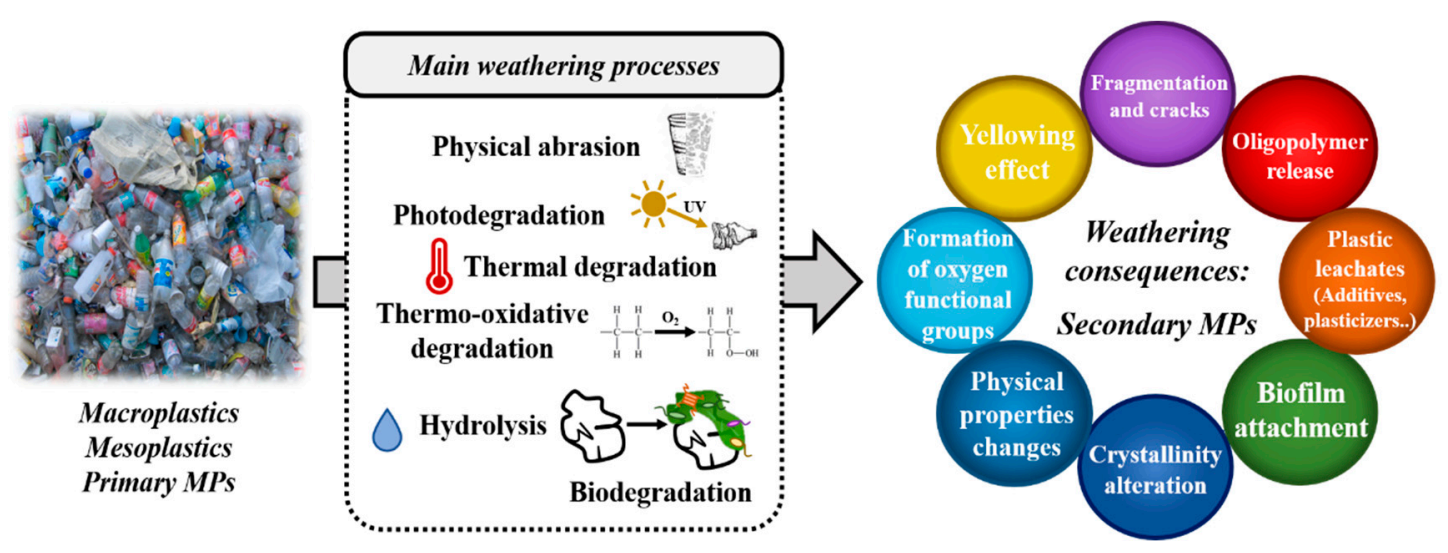

Figure 4. Overview of the main weathering processes and alterations produced on large plastic debris or primary MPs to form secondary MPs on marine environments.

\subsection{Chemical Properties of Pollutants}

Chemical properties of organic pollutants are as relevant as polymer characteristics in determining their sorption rates to plastics. For organic chemicals, hydrophobicity and molecular weight are the most relevant attributes to explain their sorption capacities. The chemical sorption coefficients on MPs are generally related to their $\mathrm{K}_{\mathrm{ow}}$ due to the hydrophobic nature of plastic surfaces. For instance, Huffer and Hoffman concluded that hydrophobicity interactions are the most important to predict chemical-plastic interaction. However, they underline that $\log \mathrm{K}_{\mathrm{ow}}$ was not a good descriptor for the sorption process [53]. In contrast, the molecular weight might become more relevant than $\mathrm{K}_{\mathrm{ow}}$ 
if diffusion was the rate-limiting process. Similarly, molecular size could play a critical role in the sorption coefficient for hydrophilic contaminants [72].

Another chemical property that may have a significant impact on the MPs sorption rates is the $\mathrm{pK}_{\mathrm{a}} \cdot \mathrm{pH}$ has a considerable influence on the modulation of MPs-pollutant interactions. For that reason, $\mathrm{pK}_{\mathrm{a}}$ may determine whether chemicals sorbed to MPs might be more prone to be released when external $\mathrm{pH}$ significantly varies. Consequently, $\mathrm{pK}_{\mathrm{a}}$ could explain which environmental pollutants would be more likely to be desorbed under physiological conditions [57]. The three-dimensional geometry of the molecule could also influence their sorption rate. Planar molecules typically have higher sorption coefficients than non-planar molecules of similar hydrophobicity due to the stronger surface adsorption showed by planar molecules. This fact could be explained because planar chemicals can move closer to the plastic surface than bulkier non-planar molecules [49]. For instance, examples of planar organic compounds are PAHs and PCBs. These compounds present well-known toxicological effects (e.g., endocrine disruption, hepatotoxicity, immunotoxicity, congenital disabilities and induction of several enzymes) due to the high-affinity interaction with the aryl hydrocarbon receptor (AhR), a cellular protein [95]. These potential threats highlight the importance of performing an accurate evaluation of the toxicological consequences of the "Trojan horse" effect that plastic debris can handle, especially for MPs and NPs.

\subsection{Environmental Factors}

Surrounding environmental conditions also modulate the pollutant-plastic interaction. $\mathrm{pH}$ influence on the sorption rates depends on the specific chemical-plastic interaction due to chemical speciation. For instance, Wang et al. reported that a $\mathrm{pH}$ decrease would significantly affect the perfluorooctanesulfonate (PFOS) sorption by PS and PE, whereas perfluorooctanesulfonamide (PFOSA) adsorption was independent of this variation. This fact indicated that PFOS-plastic sorption mechanisms undergo through electrostatic interactions [96]. Similarly, Yu et al. concluded that pH had a relevant impact on the sorption capacity of tetrabromobisphenol A (TBBPA) on microplastic beads. In this case, a decrease of the $\mathrm{pH}$ led to an increment of the sorption rate of this flame-retardant compound [97]. In agreement with these results, Elizalde-Velázquez et al. exposed that the pattern of nonsteroidal anti-inflammatory drugs (NSAID) sorption on MPs exhibited a pronounced $\mathrm{pH}$ dependency due to the $\mathrm{pH}$ effect on the speciation of the compounds and the surface charge of the particle [98]. In contrast, Holmes et al. exposed that higher sorption was observed as the $\mathrm{pH}$ of the solution increased for metals producing cationic species (e.g., $\mathrm{Pb}^{2+}, \mathrm{Cd}^{2+}, \mathrm{Ni}^{2+}, \mathrm{Co}^{2+}$ ). The authors suggested that the decline in the relative abundance of free ions could explain this experimental observation [82].

Moreover, other environmental factors such as ionic strength, salinity or the presence of DOM could also influence the sorption and desorption of chemicals from plastics on aquatic environments. The relevance of the ionic strength depends on the extent of the electrostatic interactions involved in the sorption/desorption mechanisms. For example, the study performed by Wang et al. exposed that the increase of the ionic strength only affected the sorption of PFOS, whereas PFOSA adsorption was independent. This difference indicated that PFOS sorption mechanisms to plastic undergo through electrostatic interactions [96].

Salinity influence on the sorption capacities of chemicals by plastics is critical as it enables the differentiation of freshwater and marine environments. In this case, an increased salinity can neutralize the surface charges upon MPs via the compression of the electric double layer, which lowers the role of electrostatic interactions in the sorption of MPs. The high salinity also induces the salting-out effect of chemicals and, consequently, affects the chemicals partitioning between water and plastic [76]. In the study performed by Velzeboer et al., an increase of salinity led to enhanced sorption of PCBs. Furthermore, the salinity may influence the aggregation state of the plastic particles, increasing this effect in the smallest ones. Therefore, the sorption of organic chemicals by MPs is expected to be different in freshwaters and marine environments. Xu et al. reported that the salinity did not affect 
the sorption of PDBEs when considering four types of MPs [81]. Similarly, Guo et al. concluded that the sorption capacity of sulfamethoxazole onto six plastic types (PET, PS, PP, PE, PA, and PVC) was reduced with a salinity increase. Overall, the salinity effect on sorption/desorption processes is dependent on the specific chemical-polymer interaction [99].

The presence of DOM could also affect the sorption processes of chemicals by plastics as DOM competes with other chemicals for adsorption sites on the surface of the plastics. For instance, Shen et al. observed that the humic acid pre-treatment decreased the tetracycline sorption by PE [100]. Furthermore, DOM enables changes in plastics properties due to their interaction, facilitating the interplay of plastics with hydrophilic chemicals. For instance, Zhang et al. concluded that the sorption of oxytetracycline on aged PS was promoted by the presence of humic acids. The authors exposed that the interaction of this polar pollutant via complexation could explain this fact [101]. The results observed by Qiao et al. also pointed out in the same vein. They noted that the presence of DOM promoted the adsorption of Cu on PS-MPs [102]. Despite that, other authors suggested that the presence of DOM may decrease the adsorption of antibiotics by PE [103].

These findings led to conclude that environmental influence on the sorption capacities of chemicals by plastics is strongly related to each specific interaction. For that reason, a better understanding of the sorption/desorption mechanisms between the most toxic chemicals (e.g., PCBs, PAHs, PBDEs) and the most abundant plastic types in marine environments (e.g., PE, PS, PP) is essential.

\section{Effects of MPs-pollutants Interaction on Biota}

As introduced above, MPs possess the ability to sorb organic chemicals due to their hydrophobic surface. Thereupon, pollutants may desorb from the plastics leading to an increment of their bioavailability to aquatic organisms. This capacity has led to the hypothesis that, in addition to direct effects on their interactions with biota (e.g., entanglement, ingestion), MPs might also play a significant role in aquatic ecotoxicology as vectors for toxic compounds. This hypothesis is still on the debate within the scientific literature. There are three possible scenarios which will be described below and graphically summarized in Figure 5. These different options should be analysed in-depth to accurately assess the real potential of MPs as carriers of hazardous chemicals and characterize the possible effects on the bioaccumulation and bioavailability of these compounds through MPs ingestion.

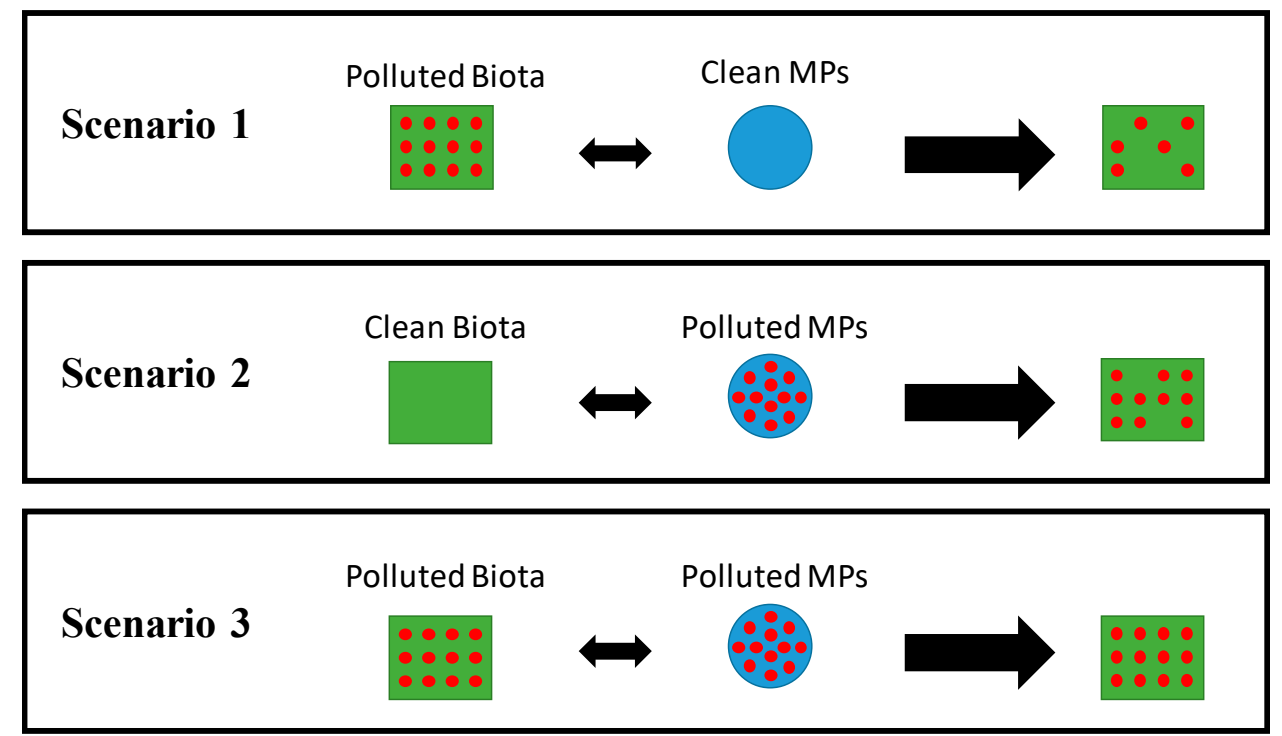

Figure 5. Schematic representation of the three possible bioaccumulation scenarios to assess the role of MPs (blue circles) as vectors of environmental pollutants (red dots) in marine biota (green squares). 


\subsection{Scenario 1: Contaminated Biota Eats Clean Plastics}

In this scenario, contaminated marine biota ingests clean microplastic pellets without sorbed environmental pollutants (see Figure 5). The ingestion of these clean microplastic beads may enable a chemical contaminant reduction in animals body. In other words, MPs could act as a sink for the bioaccumulation decrease. In this process, two simultaneous mechanisms may occur. Firstly, initial strong sorption of the chemicals to the MPs followed by desorption at a lower rate, allowing the decrease in the bioaccumulation of pollutants. Several authors have reported this cleaning effect. Koelmans et al. evaluated a conceptual model that simulated the impacts of plastic on the bioaccumulation of POPs. Results suggested increased bioaccumulation by ingestion of plastic-containing POPs and a decreased bioaccumulation by ingestion of clean plastics [64].

Similarly, Gouin et al. reported that bioaccumulation declined for compounds with a log $\mathrm{K}_{\mathrm{ow}}$ between 6.5 and 7.5. The authors presented over a twenty per cent reduction in body burden concentrations as a consequence of including a ten per cent of MPs in the diet. These results can be justified by the high sorption affinity assumed by polyethene [104]. Granby et al. also described that for a wide variety of pollutants (e.g., PCBs, PBDEs, methyl mercury, PFOS, perfluorooctanoic acid (PFOA), PFOSA and perfluorononanoic acid (PFNA)), the presence of clean MPs in contaminated feed increased the elimination coefficient from European seabass (Dicentrarchus labrax) [105]. In contrast, Rummel et al. exposed that uncontaminated polyethylene microspheres had no significant effect on the depuration rates of PCBs in an in-vivo fish feeding experiment (rainbowfish, Oncorhynchus mykiss) [106].

Finally, it should be mentioned that this scenario is currently unlikely to occur. On the one hand, most of the manufactured plastics incorporate in their surface several chemicals to improve their properties. On the other hand, MPs that are ingested are likely to sorb a wide variety of environmental pollutants before being eaten by biota.

\subsection{Scenario 2: Clean Biota Consumes Contaminated Plastics}

This scenario is the opposite of the previous one in which non-contaminated marine animals ingest contaminated MPs. Most of the reported bioaccumulation studies consider this scenario because, in this case, the experimental exposures in the laboratory are easier to perform. For instance, Granby et al. reported that the presence of the MPs with sorbed pollutants (see details in the previous scenario) decreased their elimination coefficient in seabass compared to the feed containing only pollutants [105]. Avio et al. suggested that MPs could efficiently favour the bioaccumulation of pyrene in mussel tissues. In this work, the authors concluded that an elevated desorption and bioconcentration process of this chemical occurred from MPs to mussel under physiological gut conditions [107]. In addition, Teuten et al. also explained that feeding chicks of streaked shearwater (Calonectris leucomelas) with MPs naturally contaminated from the Tokyo Bay (PCBs concentrations ranging from 51 to $562 \mathrm{ng} \mathrm{g}^{-1}$, with a mean of $97 \mathrm{ng} \mathrm{g}^{-1}$ ) implied an enhancement of PCBs bioaccumulation [54]. Similarly, Rochman et al. reported that polyethylene ingestion enabled the increased bioaccumulation of PAHs, PCBs and PBDEs [31]. However, Devriese et al. concluded that three weeks of exposition to PCBs-loaded PE microspheres did not lead to significant bioaccumulation of these pollutants in the Norway lobster (Nephrops norvegicus) [108].

At this point, it should be highlighted that environmental pollutants such as POPs can be found almost everywhere. For this reason, recent studies have focused on the study of other emerging pollutants. For these chemicals, MPs could act as a vector to increase their bioavailability. For example, Zhang et al. suggested that polystyrene microspheres might enhance the bioaccumulation of roxithromycin, a semi-synthetic macrolide antibiotic, in the freshwater fish red tilapia (Oreochromis niloticus) [109]. Similarly, the concentrations found in loach liver tissue of the antidepressant venlafaxine and its metabolites were significantly higher for the coexposure treatment group (venlafaxine + PVC microplastic) in comparison to the exposure of the chemical alone [110]. Moreover, the metabolism of chemicals by metallothionein-like proteins (MTLP) was demonstrated to be inhibited by the presence of MPs [110]. In contrast, Beiras et al. reported that polyethylene MPs (with a nominal size between 4 and 
$6 \mu \mathrm{m}$ ) did not increase the bioaccumulation of nonylphenol (usually released in the environment by the degradation of the most common non-ionic surfactants used in detergents and cleaning products) and 4-Methylbenzylidene-camphor (4-MBC, which is widely used in UV filters and sunscreens) in marine zooplankton [111]. Another important group of chemicals in which this scenario may be relevant in bioaccumulation investigations are plastic additives, as MPs may well increase their bioavailability. Sala et al. assessed the organophosphorus flame-retardant (OPFR) levels in dolphins from Southern European waters. These compounds have been widely used as plastic additives since the 1960s. This study showed that OPFRs were found in the $100 \%$ of the marine mammals studied, and the total OPFRs levels reached up to $24.7 \mathrm{ng} \mathrm{g}^{-1}$. The authors concluded that marine plastic litter could be an important source of bioaccumulation and biomagnification of OPFRs substances into marine mammals which could explain the similar concentration levels in tissues to halogenated flame retardants despite the large differences in the production volume of these families of compounds (i.e., production volume of OPFRs used as flame-retardant is roughly the half of the halogenated flame retardants production volume). In addition, the authors pointed to the lower capacity of OPFRs to bioaccumulate and biomagnify, which could indicate other pollution sources complementary to their use as flame retardants [112]. Chen et al. investigated the Bisphenol-A (BPA) bioaccumulation enhancement in zebrafish due to the presence of NPs. Results demonstrated that the presence of NPs led to the highest levels of BPA in the head and viscera of the zebrafish. Conversely, BPA muscle and gill concentrations did not significantly vary among treatments [113].

These results lead to highlight the importance of analysing bioaccumulation rates in different tissues to better understand the hazard and risk posed by exposure to plastic particles in the presence of chemicals.

\subsection{Scenario 3: Contaminated Biota Ingests Contaminated Plastics}

Finally, the third scenario represents the most prevalent biota-MPs interaction as neither of the oceans and freshwaters systems in the world are clean enough [14,87,114]. For that reason, biota is likely to bioaccumulate organic pollutants such as POPs through respiration or their diet (i.e., biomagnification). MPs and marine biota presumably reached the sorption equilibrium before animals ingested them. Consequently, many authors argue that the ingestion of MPs located in the same ecosystem does not enhance the pollutants bioaccumulation on marine animals. For instance, Herzke et al. found that POPs concentration in liver and muscle tissues of northern fulmar (Fulmarus glacialis) did not differ between plastic ingestion subgroups. For that reason, the authors concluded that marine biota would tend to bioaccumulate POPs regardless of the MPs consumption [66].

Similarly, Khan et al. suggested that PE microbeads with a size range of 10-106 $\mu \mathrm{m}$ did not increase the Ag uptake and bioaccumulation in zebrafish (Danio rerio) adults [115]. Rochman et al. could not determine any relationship between several hydrophobic organic compounds (HOCs) sorbed in MPs (e.g., PCBs, BPA, and alkylphenols) and amphipods. In spite of these results, a positive correlation was established between plastic ingestion and bioaccumulation of 183-209 PBDEs congeners in fish tissues [116]. In this work, the authors also found that lower chlorinated PCB congeners (mono to tetra) were significantly higher in lantern fish in the gyre and positively correlated with plastic density. Their results demonstrated that MPs could be a source of exposure to lower chlorinated PCBs [117]. Tanaka et al. also concluded that MPs found in oceanic seabirds (short-tailed shearwaters, Puffinus tenuirostris) stomachs might be the cause of higher PDBEs bioaccumulation in their abdominal adipose tissue [118]. All these results might confirm the role of MPs as vectors for contaminants in aquatic ecosystems, reflecting the main conclusion reported in Section 2. Therefore, as sorption/desorption mechanisms strongly depend on the specific plastic-chemical interactions, in addition of the particular environmental conditions, it is possible that contradictory results can be seen when several field investigations are compared due to the inherent complexity of the studies performed.

Summarizing, the influence of MPs on the bioavailability of environmental pollutants should not be underestimated, as it has been demonstrated that their effect is not negligible. The complexity of 
these studies caused by several factors that may influence the sorption/desorption mechanisms produce that contradictory results are obtained in similar bioaccumulation investigations. Therefore, these different scenarios should be deeply analysed to extract more accurate information about the real ecotoxicological influence of the MPs "Trojan horse" effect. It is also important to keep in mind that the presence of MPs may also enhance the bioavailability of emerging pollutants (e.g., pharmaceuticals, flame-retardant compounds, and plasticizers). For this reason, the lack of bioaccumulation and biomagnification research of these compounds due to MPs desorption should be urgently redressed.

\section{Ecotoxicological Effects of MPs Combined with Sorbed Chemicals on Biota}

Many recent publications have also focused on the assessment of the ecotoxicological effects that the pollutant-MPs interaction could cause on marine biota in comparison with the individual impacts produced for both contaminants. In other words, the potential synergistic or antagonistic effect that their interaction can produce is nowadays a new subject of study.

In Table 1, studies dealing with the interaction between MPs and inorganic pollutants are presented. Most of these works evaluated the acute toxicity of the individual pollutants and their mixture by evaluating toxicological parameters such as the survival rate, grown inhibition and post-predatory performance. Otherwise, only a reduced number of studies analysed chronic toxicity of the metal-MPs interaction. In these works, the most common assay is the assessment of several known biomarkers involved in crucial functions for survival as oxidative stress, neurotoxicity or immune responses (e.g., acetylcholinesterase (AChE), superoxide dismutase (SOD), lipid peroxidation (LPO), 7-ethoxyresorufin O-deethylase (EROD)). Almost all the research exposed that mixtures MPs-pollutant enhanced the toxicity in comparison to the individual pollutants. Despite this fact, some studies do not lead to that conclusion. Davarpanah et al. found that in the range of the concentrations analysed $(0.02$ to $0.64 \mathrm{mg} \mathrm{Cu} / \mathrm{L})$, the toxicity of copper did not increase when it was combined with MPs $(0.184 \mathrm{mg} / \mathrm{L})$ [119]. Fu et al. also studied the MPs-Cu interaction (10 mg MPs/L combined with $0.5 \mathrm{mg} \mathrm{Cu} / \mathrm{L}$ ) on microalgae. In contrast to Davarpanah, their results concluded that several toxicity parameters suffered a significant increase after ten days of exposure [92]. These conflicting conclusions could be explained due to the different range of studied MPs concentrations as well as the exposure time. Consequently, as some of the tested concentration levels were environmentally relevant, the considered exposure time may be insufficient to obtain significant changes in the average specific growth rate of Tetraselmis chuii. 
Table 1. Studies assessing the synergetic/antagonistic effect of inorganic pollutants combined with MPs.

\begin{tabular}{|c|c|c|c|c|c|c|c|c|}
\hline $\begin{array}{l}\text { MP } \\
\text { Type }\end{array}$ & MP Size & $\begin{array}{l}\text { Chemical } \\
\text { Sorbate }\end{array}$ & Exposure Concentrations * & $\begin{array}{l}\text { Exposure } \\
\text { Time }\end{array}$ & Organism & $\begin{array}{c}\text { Toxicological } \\
\text { Assessment }\end{array}$ & Highlight Results & Ref. \\
\hline PS-COOH & $\begin{array}{c}\text { Average } \\
\text { diameter: } 191.3 \\
\mathrm{~nm}\end{array}$ & Nickel & $\begin{array}{c}\text { Ni alone } \\
{[\mathrm{Ni}]=1,2,3,4, \text { and } 5 \mathrm{mg} / \mathrm{L}} \\
\text { MPs alone } \\
{[\mathrm{MPs}]=1,5,10,20,30 \mathrm{mg} / \mathrm{L}} \\
\text { Variable Ni-Fixed MPs } \\
{[\mathrm{Ni}]=1,2,3,4, \text { and } 5 \mathrm{mg} / \mathrm{L}} \\
{[\mathrm{MPs}]=5 \mathrm{mg} / \mathrm{L}} \\
\frac{\text { Fixed Ni-Variable MPs }}{[\mathrm{Ni}]=3 \mathrm{mg} / \mathrm{L}} \\
{[\mathrm{MPs}]=1,5,10,20,30 \mathrm{mg} / \mathrm{L}} \\
\frac{\text { Variable Ni-Variable MPs }}{1 \mathrm{mg} / \mathrm{L} \mathrm{Ni}-1 \mathrm{mg} / \mathrm{L} \mathrm{MP}} \\
2 \mathrm{mg} / \mathrm{L} \mathrm{Ni}-5 \mathrm{mg} / \mathrm{L} \mathrm{MP} \\
5 \mathrm{mg} / \mathrm{L} \mathrm{Ni}-30 \mathrm{mg} / \mathrm{L} \mathrm{MP}\end{array}$ & $48 \mathrm{~h}$ & Daphnia magna & $\begin{array}{l}\text { Rate of abnormalities } \\
\text { and changes in the } \\
\text { morphology } \\
\text { Rate of immobilization }\end{array}$ & $\begin{array}{c}\text { Enhanced toxicity of Ni in } \\
\text { combination with both MPs } \\
\text { Higher immobilization } \\
\text { effect for Ni - PS-COOH } \\
\text { exposure } \\
\text { Ni showed an antagonistic } \\
\text { effect on toxicity with PS } \\
\text { and synergistic with } \\
\text { PS-COOH } \\
\text { Results may indicate that } \\
\text { the toxic effects of MPs and } \\
\text { Ni vary depending of the } \\
\text { properties of both } \\
\text { pollutants }\end{array}$ & [120] \\
\hline PE & $1-5 \mu \mathrm{m}$ & $\begin{array}{l}\text { Chromium } \\
\text { (VI) }\end{array}$ & $\begin{array}{c}\mathrm{Cr}(\mathrm{VI}) \text { alone } \\
\mathrm{Cr}(\mathrm{VI})]=0, \frac{1}{5.6,8.4,12.6,18.9} \text { and } 28.4 \\
\mathrm{mg} / \mathrm{L} \\
\frac{\mathrm{MPs} \text { alone }}{[\mathrm{MPs}]=0.184 \mathrm{mg} / \mathrm{L}} \\
\mathrm{MPs}+\mathrm{Cr}(\mathrm{VI}) \\
\begin{array}{c}\text { Co-exposure performed using the same } \\
\text { concentrations of single treatments }\end{array}\end{array}$ & $96 \mathrm{~h}$ & $\begin{array}{c}\text { Early juveniles } \\
\text { of the common } \\
\text { goby fish } \\
\text { (Pomatoschistus } \\
\text { microps) }\end{array}$ & $\begin{array}{c}\text { Post-predatory } \\
\text { performance assay } \\
\text { The activities of AChE, } \\
\text { GST, EROD activities } \\
\text { LPO levels }\end{array}$ & $\begin{array}{l}\text { Significant decrease of the } \\
\text { predatory performance and } \\
\text { significant inhibition of } \\
\text { AChE activity under } \\
\text { simultaneous exposure } \\
\text { Long-term exposure to } \\
\text { different environmental } \\
\text { conditions in } \\
\text { developmental phases } \\
\text { influences the response of } \\
\text { early juveniles }\end{array}$ & [121] \\
\hline PS & $32-40 \mu \mathrm{m}$ & Cadmium & 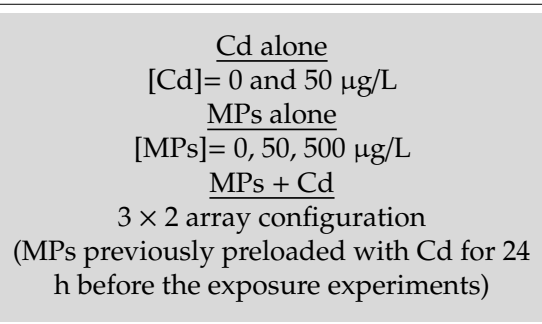 & 30 days & $\begin{array}{l}\text { Early juveniles } \\
\text { of discus fish } \\
\text { (Symphysodon } \\
\text { aequifasciatus) }\end{array}$ & $\begin{array}{c}\text { Survival rate } \\
\text { Body length } \\
\text { The activities of SOD, } \\
\text { CAT, GPx, LZM, ACP } \\
\text { and ALP } \\
\text { The level of GSH and } \\
\text { C3 } \\
\text { The concentrations of } \\
\text { MDA and PC }\end{array}$ & $\begin{array}{l}\text { The MP }+ \text { Cd mixture } \\
\text { induced severe oxidative } \\
\text { damage as well as the } \\
\text { stimulation of the immune } \\
\text { system } \\
\text { Co-exposure stimulate the } \\
\text { innate immune responses } \\
\text { of early juveniles }\end{array}$ & [122] \\
\hline
\end{tabular}


Table 1. Cont

\begin{tabular}{|c|c|c|c|c|c|c|c|c|}
\hline $\begin{array}{l}\text { MP } \\
\text { Type }\end{array}$ & MP Size & $\begin{array}{c}\text { Chemical } \\
\text { Sorbate }\end{array}$ & Exposure Concentrations * & $\begin{array}{l}\text { Exposure } \\
\text { Time }\end{array}$ & Organism & $\begin{array}{c}\text { Toxicological } \\
\text { Assessment }\end{array}$ & Highlight Results & Ref. \\
\hline PS & $5 \mu \mathrm{m}$ & Cadmium & $\begin{array}{c}\frac{\mathrm{Cd} \text { alone }}{[\mathrm{Cd}]=10 \mu \mathrm{g} / \mathrm{L}} \\
\mathrm{MPs}+\mathrm{Cd} \\
10 \mu \mathrm{g} / \mathrm{L} \mathrm{Cd}-20 \mu \mathrm{g} / \mathrm{L} \mathrm{MPs} \\
10 \mu \mathrm{g} / \mathrm{L} \mathrm{Cd}-200 \mu \mathrm{g} / \mathrm{L} \mathrm{MPs} \\
\text { (MPs incubated during 96h before the } \\
\text { exposure experiments) }\end{array}$ & 3 weeks & $\begin{array}{l}\text { Zebrafish } \\
\text { (Danio rerio) }\end{array}$ & $\begin{array}{l}\text { Histological analysis } \\
\text { (liver, gut and gills) } \\
\text { GSH and MT levels } \\
\text { SOD activity } \\
\text { mRNA levels of } 8 \text { target } \\
\text { genes in zebrafish } \\
\text { tissues }\end{array}$ & $\begin{array}{l}\text { Enhanced toxicity of Cd in } \\
\text { combination with MPs } \\
\text { Oxidative stress and early } \\
\text { inflammatory responses } \\
\text { observed in the mixture } \\
\text { treatments } \\
\text { Important changes in the } \\
\text { gene expression observed } \\
\text { for all co-exposure } \\
\text { treatments }\end{array}$ & [123] \\
\hline unknown & $1-5 \mu \mathrm{m}$ & Mercury & $\begin{array}{c}{[\mathrm{Hg}]=0.010 \text { alone }} \\
{[\mathrm{MPs}]=\frac{\text { MPs alone } 0.016 \mathrm{mg} / \mathrm{L}}{0.26 \text { and } 0.69 \mathrm{mg} / \mathrm{L}}} \\
\frac{\mathrm{MPs}+\mathrm{Hg}}{4 \text { binary mixtures using the same }} \\
\text { concentrations of single exposures }\end{array}$ & $96 \mathrm{~h}$ & $\begin{array}{c}\text { Juvenile } \\
\text { European } \\
\text { seabass } \\
\text { (Dicentrarchus } \\
\text { labrax) }\end{array}$ & $\begin{array}{l}\text { AChE, ChE, IDH and } \\
\text { LDH activities } \\
\text { LPO levels }\end{array}$ & $\begin{array}{l}\text { A significant interaction } \\
\text { between MPs and Hg was } \\
\text { achieved } \\
\text { Biomarkers' variation was } \\
\text { highly influenced by the } \\
\text { concentration of MPs }\end{array}$ & [124] \\
\hline unknown & $1-5 \mu \mathrm{m}$ & Mercury & 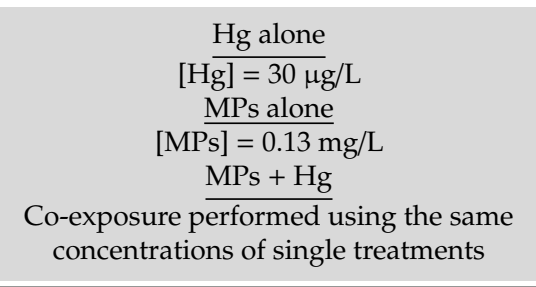 & $\begin{array}{l}8 \text { days } \\
(+6 \text { days } \\
\text { in clean } \\
\text { medium })\end{array}$ & $\begin{array}{l}\text { Freshwater } \\
\text { bivalve } \\
\text { (Corbicula } \\
\text { fluminea) }\end{array}$ & $\begin{array}{l}\text { The post-exposure } \\
\text { filtration rate } \\
\text { ChE, IDH, GST, GSR, } \\
\text { GPx, ODH and CAT } \\
\text { activities } \\
\text { LPO levels }\end{array}$ & $\begin{array}{l}\text { Antagonistic behaviour } \\
\text { between MPs and Hg in } \\
\text { several biomarkers } \\
\text { Six days of post-exposure } \\
\text { recovery in the clean } \\
\text { medium was not enough to } \\
\text { reverse the toxic effects } \\
\text { induced by both pollutants }\end{array}$ & [125] \\
\hline PE & $10-45 \mu \mathrm{m}$ & Mercury & $\begin{array}{c}\frac{\mathrm{Hg} \text { alone }}{[\mathrm{Hg}]=10 \mu \mathrm{g} / \mathrm{L}} \\
\mathrm{MPs} \text { alone } \\
{[\mathrm{MPs}]=25 \mu \mathrm{g} / \mathrm{L}} \\
\text { MPs }+\mathrm{Hg}\end{array}$ & 7 days & $\begin{array}{l}\text { Manila clam } \\
\text { (Ruditapes } \\
\text { philippinarum) }\end{array}$ & $\begin{array}{l}\text { Histological analysis } \\
\text { (gill and digestive } \\
\text { gland) } \\
\text { Filtration rates } \\
\text { Immunomodulation } \\
\text { Oxidative stress }\end{array}$ & $\begin{array}{l}\text { The filtration rates } \\
\text { decreased as a result of the } \\
\text { co-exposure } \\
\text { A higher decrease in } \\
\text { haemocyte viability was } \\
\text { detected in co-exposure } \\
\text { treatments } \\
\text { Antioxidant parameters } \\
\text { remain unchanged in the } \\
\text { mixture in comparison to } \\
\text { single treatments }\end{array}$ & [7] \\
\hline
\end{tabular}


Table 1. Cont

\begin{tabular}{|c|c|c|c|c|c|c|c|c|}
\hline $\begin{array}{l}\text { MP } \\
\text { Type }\end{array}$ & MP Size & $\begin{array}{l}\text { Chemical } \\
\text { Sorbate }\end{array}$ & Exposure Concentrations * & $\begin{array}{l}\text { Exposure } \\
\text { Time }\end{array}$ & Organism & $\begin{array}{l}\text { Toxicological } \\
\text { Assessment }\end{array}$ & Highlight Results & Ref. \\
\hline PE & $1-5 \mu \mathrm{m}$ & Copper & $\begin{array}{c}\mathrm{Cu \text {alone }} \\
{[\mathrm{Cu}]=0.02,0.04,0.08,0.16,0.32 \text { and } 0.64} \\
\mathrm{mg} / \mathrm{L} \\
\frac{\mathrm{MPs} \text { alone }}{0.092,0.184,0.368,0.736} \\
\text { and } 1.472 \mathrm{mg} / \mathrm{L} \\
\mathrm{MPs}+\mathrm{Cu}\end{array}$ & $96 \mathrm{~h}$ & $\begin{array}{c}\text { Marine } \\
\text { microalgae } \\
\text { (Tetraselmis } \\
\text { chuii) }\end{array}$ & $\begin{array}{l}\text { The average specific } \\
\text { growth rate and the } \\
\text { percentage of growth } \\
\text { inhibition }\end{array}$ & $\begin{array}{l}\text { No significant differences } \\
\text { were observed between } \\
\text { treatments with and } \\
\text { without MPs } \\
\text { MPs did not influence the } \\
\text { Cu toxicity }\end{array}$ & [119] \\
\hline $\begin{array}{l}\text { Aged } \\
\text { PVC }\end{array}$ & D50:132 $\mu \mathrm{m}$ & Copper & 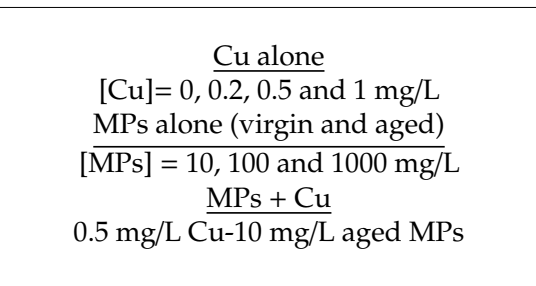 & 10 days & $\begin{array}{l}\text { Microalgae } \\
\text { (Chlorella } \\
\text { vulgaris) }\end{array}$ & $\begin{array}{l}\text { The growth inhibition } \\
\text { ratio (IR) and biomass } \\
\text { productivity } \\
\text { The enzymatic activities } \\
\text { of SOD and MDA }\end{array}$ & $\begin{array}{l}\text { Mixture exposure enhances } \\
\text { the cell growth in } \\
\text { comparison to single } \\
\text { treatments } \\
\text { The ageing of MPs poses } \\
\text { stronger inhibitory effects } \\
\text { in microalgae than virgin } \\
\text { pellets }\end{array}$ & [92] \\
\hline PS & $\begin{array}{l}0.1 \mu \mathrm{m} \\
20 \mu \mathrm{m}\end{array}$ & Copper & $\begin{array}{c}\frac{\mathrm{Cu} \text { alone }}{[\mathrm{Cu}]=50 \mu \mathrm{g} / \mathrm{L}} \\
\text { MPs alone } \\
{[\mathrm{MPs}]=200 \mu \mathrm{g} / \mathrm{L}} \\
\mathrm{MPs}+\mathrm{Cu} \\
\text { Combination of concentrations used in } \\
\text { single treatments }\end{array}$ & 14 days & $\begin{array}{l}\text { Zebrafish (Danio } \\
\text { rerio) }\end{array}$ & $\begin{array}{c}\text { SOD, MDA and MT } \\
\text { levels } \\
\text { Transcriptomic analysis }\end{array}$ & $\begin{array}{c}\text { Synergetic effects in } \\
\text { co-exposure treatments of } \\
\text { small MPs were observed } \\
\text { The presence of MPs and } \\
\text { DOM aggravates the } \\
\text { Cu-toxicity }\end{array}$ & [102] \\
\hline
\end{tabular}

* Shadowed cells represent environmental relevant concentrations. 
POPs are by far the group of chemicals most studied when considering the toxicity of their interaction with MPs. Several families of compounds can be highlighted such as PAHs (e.g., phenanthrene, fluoranthene), PCBs, PBDEs and polyfluoroalkyl substances (PFAS). Table 2 shows that most of these studies concluded that the mixture of both pollutants caused higher toxic effects in comparison to the individual exposition. However, other studies, such as the one presented by Guven et al., did not reach the same conclusions as to the combined exposure of pyrene and PS-divinylbenzene plastic microspheres did not magnify the PAH acute single impact [126]. Again, differences between studies can be attributed to several factors such as the different exposure times, concentration levels used for both pollutants, and analysed organisms.

It is important to highlight that the chronic exposure evaluation of POPs-MPs toxic interaction was more studied compared to other groups of chemicals such as heavy metals or pharmaceuticals. Moreover, there are some studies in which their exposure mixtures were prepared in the real environment [127]. Other relevant differences between these studies are the evaluated toxicological parameters. Here, gene expression analysis and biomarker performance changes are the most common. In a few cases, the survival rate or the post-predatory assay were considered.

Finally, the synergistic or antagonistic effects of the combination of MPs with other organic chemicals produced in biota are summarized in Table 3. Organic pesticides (e.g., chlorpyrifos), plasticizers (e.g., BPA) or pharmaceuticals (e.g., roxithromycin) are examples of these alternative chemical families. Similarly to heavy metals-MPs studies, most of these works considered an acute toxicity evaluation of the interaction. Hence, mortality rates, grown inhibition and morphology changes are the most studied toxicological parameters. As shown in Table 3, toxicological results lead to the conclusion that MPs enhance the ecotoxic effects of the chemicals tested.

The overall results led to conclude that the interaction between MPs and the different groups of environmental pollutants cannot be neglected under standard experimental conditions. However, it is still difficult to achieve a conclusion regarding if these results are likely to mimic environmental conditions. This concern occurs as most of the experimental studies use concentration levels that are not always consistent with the concentrations found in environmental conditions, as they are usually higher. Moreover, several microplastic toxic analyses include the use of an ultrasonic bath or surfactants (e.g., Tween-20 or Tween-80) to obtain the dispersion of the MPs and maintain homogeneous suspensions. For that reason, observed toxic effects in aquatic organisms may correspond to high pollutant stress. Despite that, as highlighted in the work by Ngoc et al., MPs and NPs concentration levels in marine environments are not likely to decrease. For that reason, the study of the biological impacts on organisms after acute exposition may also be of great interest [128]. Ideally, a realistic scenario, in which several types of MPs are exposed to different mixtures of chemicals in environmentally relevant concentrations should always be performed. Moreover, testing several organisms which represent different levels of the food chain (e.g., zooplankton, microalgae, early juveniles and fish) is also required. Besides, the toxicological assessment on cell cultures could provide in vitro models to model the effects of these environmental pollutants at the cellular level. Unfortunately, these types of studies cannot be easily performed. Many reasons prevent these studies, such as the complexity of the experimental work or the lack of animal models.

Most toxicological works use PE and PS (with fewer examples employing PVC) to conduct the individual and interaction studies. This selection is consistent with the polymeric amount found in the marine plastic debris where both PE and PS are the most detected polymers. Additionally, the study of both individual and combined effects of pollutants with bioplastics may be beneficial as their production is currently increasing. The size-dependent effect should also be urgently assessed. As several toxicological studies reported [61,113,129], smaller plastic particles cause enhanced harmful effects. For this reason, the assessment of the toxicological impact of NPs and their interaction with other environmental pollutants is also needed. Similar studies to those performed by Kim [120] and $\mathrm{Fu}$ [92] should be carried out, providing an in-depth evaluation of the combined effects of pollutants with ageing plastics. Due to the high persistence of these compounds, the belief that most of the plastic debris present in marine ecosystems have been exposed to several degradation processes seems logical. 
Table 2. Studies assessing the possible synergetic/antagonistic effect of persistent organic compounds (POPs) combined with MPs.

\begin{tabular}{|c|c|c|c|c|c|c|c|c|}
\hline MP Type & MP Size & Chemical Sorbate & Exposure Concentrations & $\begin{array}{c}\text { Exposure } \\
\text { Time }\end{array}$ & Organism & Toxicological Assessment & Highlight Results & Ref. \\
\hline $\begin{array}{c}\text { PS- } \\
\text { divinilbenzene }\end{array}$ & $97 \mu \mathrm{m}$ & Pyrene & $\begin{array}{c}\text { Pyrene alone } \\
{[\text { Pyrene }=0.1 \mu \mathrm{M}} \\
\text { MPs alone } \\
{[\mathrm{MPs}]=100 \text { particles } / \mathrm{L}} \\
\text { MPs + Pyrene } \\
100 \mathrm{nM} \text { pyrene }+100 \text { particles } / \mathrm{L} \\
\text { MPs }\end{array}$ & $24 \mathrm{~h}$ & $\begin{array}{c}\text { Tropical fish } \\
\text { juveniles } \\
\text { (Lates calcarifer) }\end{array}$ & $\begin{array}{c}\text { Mortality rate } \\
\text { Juveniles behaviour } \\
\text { Predatory performance } \\
\text { Size differences }\end{array}$ & $\begin{array}{l}\text { Individuals exposed to both } \\
\text { pollutants were the most affected } \\
\text { group, but the negative impact } \\
\text { was relatively small }\end{array}$ & [126] \\
\hline PS & $<100 \mu \mathrm{m}$ & Pyrene & $\begin{array}{c}\text { MPs alone } \\
{[\mathrm{MPs}]=20 \mathrm{~g} / \mathrm{L}} \\
\text { MPs + pyrene } \\
\text { Before the experiment, a solution } \\
\text { of PE or PS were incubated with } \\
\text { pyrene }(50 \mu \mathrm{g} / \mathrm{L}) \text { for } 6 \text { days }\end{array}$ & 7 days & $\begin{array}{l}\text { Marine mussel } \\
\quad \text { (Mytilus } \\
\text { galloprovincialis) }\end{array}$ & $\begin{array}{c}\text { Histological analysis (gills and } \\
\text { digestive glands) } \\
\text { Gene transcription analyses } \\
\text { Genotoxic effects } \\
\text { Immunological alterations } \\
\text { Neurotoxic responses } \\
\text { Oxidative stress } \\
\text { Antioxidant defences }\end{array}$ & $\begin{array}{l}\text { Clear separation between control } \\
\text { and MPs exposed mussels } \\
\text { Biological variations were } \\
\text { influenced by the typology of } \\
\text { polymer (PE vs PS) } \\
\text { Only genotoxic responses } \\
\text { separated virgin from pyrene- } \\
\text { contaminated polymers }\end{array}$ & [107] \\
\hline PE & $1-5 \mu \mathrm{m}$ & Pyrene & $\begin{array}{c}\text { Pyrene alone } \\
\text { [Pyrene }]=20 \text { and } 200 \mu \mathrm{g} / \mathrm{L} \\
\text { MPs alone } \\
{[\mathrm{MPs}]=0,18.4 \text { and } 184 \mu \mathrm{g} / \mathrm{L}} \\
\text { MPs + Pyrene } \\
0 \mu \mathrm{g} / \mathrm{L} \text { pyrene-18.4 } \mu \mathrm{g} / \mathrm{L} \mathrm{MPs} \\
200 \mu \mathrm{g} / \mathrm{L} \text { pyrene-184 } \mathrm{gg} / \mathrm{L} \mathrm{MPs} \\
200 \mu \mathrm{g} / \mathrm{L} \text { pyrene- } 184 \mu \mathrm{g} / \mathrm{L} \mathrm{MPs}\end{array}$ & $96 \mathrm{~h}$ & $\begin{array}{l}\text { Juveniles of the } \\
\text { common Goby } \\
\text { (Pomatoschitus } \\
\text { microps) }\end{array}$ & $\begin{array}{c}\text { Protein content } \\
\text { AChE, IDH, GST activities } \\
\text { - LPO levels } \\
\text { Bile samples were analysed for } \\
\text { pyrene metabolites }\end{array}$ & $\begin{array}{l}\text { The presence of MPs was found } \\
\text { to delay the pyrene-induced } \\
\text { mortality } \\
\text { Enhanced concentration of } \\
\text { pyrene-metabolites was detected } \\
\text { in co-exposure treatments } \\
\text { Results suggest toxicologically } \\
\text { relevant interactions between } \\
\text { both pollutants }\end{array}$ & [130] \\
\hline PHB & $10-90 \mu \mathrm{m}$ & $\begin{array}{l}\text { Fluoranthene } \\
\text { (Flu.) }\end{array}$ & $\begin{array}{c}\text { Flu. alone } \\
{[\text { Flu] }=100 \mu \mathrm{g} / \mathrm{L}} \\
\text { MPs alone } \\
{[\mathrm{MPs}]=1000 \text { particles } / \mathrm{mL}} \\
\text { MPs + Flu. } \\
\text { Flu - PE/PHB co-exposure or } \\
\text { incubation at the same } \\
\text { concentrations tested in single } \\
\text { exposures (incubation during } \\
\text { overnight) }\end{array}$ & $96 \mathrm{~h}$ & $\begin{array}{l}\text { Blue Mussel } \\
\text { (Mytilus edulis) }\end{array}$ & $\begin{array}{c}\text { Protein content in the cytosol } \\
\text { The cytosolic concentration of } \\
\text { GSH } \\
\text { SOD, CAT, GPx and SeGPx } \\
\text { activities }\end{array}$ & $\begin{array}{l}\text { In co-exposure and incubation } \\
\text { treatments, biochemical } \\
\text { responses were generally } \\
\text { comparable with those exerted } \\
\text { MPs only } \\
\text { Apparent absence of combined } \\
\text { effects of MPs with the pollutant. }\end{array}$ & [5] \\
\hline
\end{tabular}


Table 2. Cont

\begin{tabular}{|c|c|c|c|c|c|c|c|c|}
\hline MP Type & MP Size & Chemical Sorbate & Exposure Concentrations & $\begin{array}{l}\text { Exposure } \\
\text { Time }\end{array}$ & Organism & Toxicological Assessment & Highlight Results & Ref. \\
\hline PE & $10-90 \mu \mathrm{m}$ & $\begin{array}{l}\text { Fluoranthene } \\
\text { (Flu.) }\end{array}$ & 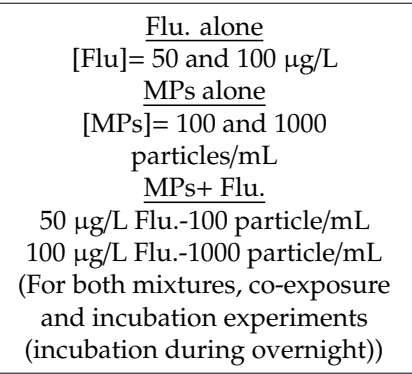 & $96 \mathrm{~h}$ & $\begin{array}{c}\text { Blue mussel } \\
\text { (Mytilus edulis) }\end{array}$ & $\begin{array}{l}\text { Total GSH + 2GSSG levels } \\
\text { SOD, CAT, GPx and SeGPx } \\
\text { activities }\end{array}$ & $\begin{array}{l}\text { No synergistic or antagonistic } \\
\text { effect was seen in the } \\
\text { co-exposure or the incubation } \\
\text { experiments }\end{array}$ & [131] \\
\hline PS & $\begin{array}{c}\text { Mix of } 2 \\
\text { and } 6 \mu \mathrm{m}\end{array}$ & $\begin{array}{l}\text { Fluoranthene } \\
\text { (Flu.) }\end{array}$ & $\begin{array}{c}\text { Flu. alone } \\
\text { [Flu] }]=30 \mu \mathrm{g} / \mathrm{L} \text { day } \\
\text { MPs alone } \\
{[\mathrm{MPs}]=32 \mathrm{mg} / \mathrm{L} \text { day }} \\
\text { MPs + Flu. } \\
30 \mu \mathrm{g} / \mathrm{L} \text { day Flu.-32 } \mathrm{mg} / \mathrm{L} \text { day PS }\end{array}$ & $\begin{array}{l}7 \text { days } \\
\text { (+ } 7 \text { days } \\
\text { of } \\
\text { depuration) }\end{array}$ & $\begin{array}{c}\text { Marine mussel } \\
\text { (Mytilus spp.) }\end{array}$ & $\begin{array}{l}\text { Morphological and functional } \\
\text { analyses of hemocytes } \\
\text { Hemocyte mortality } \\
\text { Circulating hemocytes } \\
\text { concentration } \\
\text { Phagocytosis activity } \\
\text { Histopathological assessment } \\
\text { (digestive tract and intestine) } \\
\text { ROS production } \\
\text { Levels of LPO } \\
\text { SOD, CAT, GR and GST activities } \\
\text { Gene expression analysis }\end{array}$ & $\begin{array}{c}\text { Increase in the total } \\
\text { histopathological lesions/ } \\
\text { abnormalities was demonstrated } \\
\text { in co-exposure treatments } \\
\text { After depuration, a higher } \\
\text { fluoranthene concentration was } \\
\text { detected in mussels exposed to } \\
\text { the mixture of MPs and Flu } \\
\text { Results suggested that MPs led } \\
\text { to modulated fluoranthene } \\
\text { kinetics and toxicity in marine } \\
\text { mussels. }\end{array}$ & [132] \\
\hline PS & $\begin{array}{l}500 \mathrm{~nm} \\
30 \mu \mathrm{m}\end{array}$ & $\begin{array}{c}\text { Benzo[a]pyrene } \\
\text { (B[a]P) } \\
17 \beta \text {-estradiol (E2) }\end{array}$ & $\begin{array}{c}\mathrm{B}[\mathrm{a}] \mathrm{P} \text { alone } \\
{[\mathrm{B}[\mathrm{a}] \mathrm{P}]=5 \text { and } 50 \mathrm{mg} / \mathrm{L}} \\
\underline{\mathrm{E} 2 \text { alone }} \\
{[\mathrm{E} 2]=0.1 \text { and } 1 \mathrm{mg} / \mathrm{L}} \\
\text { MPs alone } \\
{[\overline{\mathrm{MPs}}=1 \mathrm{mg} / \mathrm{L}} \\
\text { MPs }+ \text { Pollutant } \\
\text { Combination of individual } \\
\text { concentrations of MPs of both } \\
\text { sizes and the organic } \\
\text { contaminants }\end{array}$ & 4 days & $\begin{array}{l}\text { Bivalve specie } \\
\text { (Tegillarca } \\
\text { granosa) }\end{array}$ & $\begin{array}{l}\text { Analysis of total counts, cell-type } \\
\text { composition, and phagocytic } \\
\text { activity of haemocytes } \\
\text { ROS and Ca2+ concentration } \\
\text { from haemocytes } \\
\text { LZM content and activity } \\
\text { Gene expression of three major } \\
\text { types of genes }\end{array}$ & $\begin{array}{l}\text { POPs toxicity was aggravated by } \\
\text { smaller MPs and mitigated by } \\
\text { larger MPs } \\
\text { The deleterious impacts of B[a]P } \\
\text { or E2 were mitigated by the } \\
\text { presence of larger sized MPs and } \\
\text { aggravated smaller ones }\end{array}$ & [8] \\
\hline
\end{tabular}


Table 2. Cont.

\begin{tabular}{|c|c|c|c|c|c|c|c|c|}
\hline MP Type & MP Size & Chemical Sorbate & Exposure Concentrations & $\begin{array}{l}\text { Exposure } \\
\text { Time }\end{array}$ & Organism & Toxicological Assessment & Highlight Results & Ref. \\
\hline LD-PE & $20-25 \mu \mathrm{m}$ & $\begin{array}{l}\text { Benzo(a)pyrene } \\
(\mathrm{B}[\mathrm{a}] \mathrm{P})\end{array}$ & $\begin{array}{c}\text { B[a]P alone } \\
{[\mathrm{B}[\mathrm{a}] \mathrm{P}]=150 \mu \mathrm{g} / \mathrm{L}} \\
\text { MPs alone } \\
{[\mathrm{MPs}]=10 \mathrm{mg} / \mathrm{L}} \\
\mathrm{MPs}+\mathrm{B}[\mathrm{a}] \mathrm{P} \\
15 \mu \mathrm{g} / \mathrm{g} \mathrm{B}[\mathrm{a}] \mathrm{P}-10 \mathrm{mg} / \mathrm{L} \text { MPs } \\
\text { (To reach this B[a]P sorbed } \\
\text { concentration, 2 days of } \\
\text { incubation was performed) }\end{array}$ & $\begin{array}{l}7,14 \text { and } \\
28 \text { days }\end{array}$ & $\begin{array}{l}\text { Marine mussel } \\
\text { (Mytilus } \\
\text { galloprovincialis) }\end{array}$ & $\begin{array}{l}\text { Immunological alterations of } \\
\text { hemocytes } \\
\text { Neurotoxic responses in } \\
\text { hemocytes and gills } \\
\text { Oxidative stress } \\
\text { Antioxidant defences, } \\
\text { Genotoxic effects } \\
\text { Transcriptional responses }\end{array}$ & $\begin{array}{l}\text { The overall evaluation provided } \\
\text { a clear separation between times } \\
\text { and typologies of exposure } \\
\text { Significant alterations measured } \\
\text { on the immune system } \\
\text { Results suggested that the } \\
\text { toxicological risk of MPs for } \\
\text { marine organisms is probably } \\
\text { low, but not negligible }\end{array}$ & [133] \\
\hline PE & $\begin{array}{c}212-250 \\
\mu \mathrm{m}\end{array}$ & $\begin{array}{l}\text { Phenanthrene (Phe.) } \\
\text { Anthracene }\end{array}$ & $\begin{array}{c}\text { Phe. alone } \\
\text { [Phe.] }=0.12 \mu \mathrm{M} \\
\text { Anthracene alone } \\
\text { [Anthracene }=0.14 \mu \mathrm{M} \\
\text { MPs alone } \\
\text { [MPs] }=0.02 \text { and } 0.2 \mathrm{~g} / \mathrm{g} \text { sediment } \\
\text { MPs + Phe. / Anthracene } \\
\text { Lower dose of PE combined with } \\
\text { pollutants preloaded for } 96 \mathrm{~h}\end{array}$ & 2 weeks & $\begin{array}{l}\text { Bacterial } \\
\text { community of } \\
\text { sediments }\end{array}$ & Gene expression assessment & $\begin{array}{l}\text { The presence of MP reduced the } \\
\text { effect of the two PAHs on } \\
\text { microbial community } \\
\text { composition and the degradation } \\
\text { of these organic compounds }\end{array}$ & [134] \\
\hline $\begin{array}{l}\text { LD-PE } \\
\text { non-uniformly } \\
\text { shaped }\end{array}$ & $<60 \mu \mathrm{m}$ & $\begin{array}{l}\text { Phenanthrene } \\
\text { (Phe.) }\end{array}$ & $\begin{array}{l}\text { Phe. alone } \\
\text { [Phe.] } \\
=10 \text { and } 100 \mu \mathrm{g} / \mathrm{L} \\
\text { MPs alone } \\
\text { [MPs] }=50 \text { and } 500 \mu \mathrm{g} / \mathrm{L} \\
\text { MPs }+ \text { Phe. } \\
\text { Combination of individual } \\
\text { concentrations of MPs the } \\
\text { organic contaminant }\end{array}$ & $96 \mathrm{~h}$ & $\begin{array}{l}\text { African catfish } \\
\text { (Clarias } \\
\text { gariepinus) }\end{array}$ & $\begin{array}{c}\text { Histopathological analysis (liver } \\
\text { and gill) } \\
\text { Glycogen stores of the liver } \\
\text { Biomarkers responses of AST, } \\
\text { ALT, LDH, ALP, } \gamma \text { GT } \\
\text { Contents of total protein, total } \\
\text { albumin, lipase, glucose, lactate, } \\
\text { direct bilirubin, HDL, LDL, TG } \\
\text { and cholesterol } \\
\text { Gene expression analysis }\end{array}$ & $\begin{array}{c}\text { Changes in biomarker responses } \\
\text { of co-exposure treatment might } \\
\text { be due to the facilitated } \\
\text { transportation of Phe into the } \\
\text { fish body } \\
\text { Findings suggested } \\
\text { toxicologically relevant } \\
\text { interactions between MPs and } \\
\text { Phe }\end{array}$ & [135] \\
\hline PE & $\begin{array}{l}50 \mathrm{~nm} \\
500 \mathrm{~nm} \\
5 \mu \mathrm{m} \\
10 \mu \mathrm{m} \\
15 \mu \mathrm{m}\end{array}$ & $\begin{array}{l}\text { Phenanthrene } \\
\text { (Phe.) }\end{array}$ & 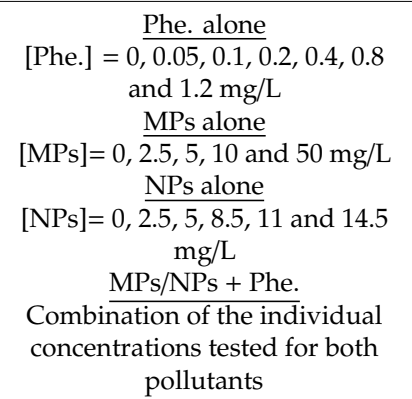 & $48 \mathrm{~h}$ & Daphnia magna & $\begin{array}{l}\text { Immobilization rate of the } \\
\text { daphnids }\end{array}$ & $\begin{array}{l}\text { Enhanced immobilization of } \\
\text { daphnia was observed in } \\
\text { co-exposure treatments } \\
\text { (especially for NPs) } \\
\text { The presence of NPs inhibited } \\
\text { the dissipation of phenanthrene } \\
\text { of the environment }\end{array}$ & [61] \\
\hline
\end{tabular}


Table 2. Cont.

\begin{tabular}{|c|c|c|c|c|c|c|c|c|}
\hline MP Type & MP Size & Chemical Sorbate & Exposure Concentrations & $\begin{array}{c}\text { Exposure } \\
\text { Time }\end{array}$ & Organism & Toxicological Assessment & Highlight Results & Ref. \\
\hline LD-PE & $\begin{array}{c}125-250 \\
\mu \mathrm{m}\end{array}$ & $\begin{array}{c}\alpha-\mathrm{HBCD} \\
\text { 2,4,6-tribromophenol } \\
\text { PBDEs mix } \\
\text { (PBDE 47, 99, 153, } \\
154) \\
\text { PCB congeners } \\
(28,52,101,118,138, \\
153,180) \\
\text { methyl mercury } \\
\text { PFOS } \\
\text { PFOA } \\
\text { PFOSA } \\
\text { PFNA }\end{array}$ & $\begin{array}{c}\text { Feed A: Basic feed (control) } \\
\text { Feed B: Basic feed }+ \\
\text { contaminants sorbed to MPs } \\
\text { before the incorporation of } 2 \% \\
\text { into pellets } \\
\text { (incubation for overnight) } \\
\text { Feed C: Basic feed }+ \\
\text { contaminants without MPs } \\
\text { Feed D: Basic feed + } \\
\text { contaminants and clean MPs }\end{array}$ & $\begin{array}{l}80 \text { days } \\
(+51 \text { days } \\
\text { of } \\
\text { depuration })\end{array}$ & $\begin{array}{c}\text { European } \\
\text { seabass } \\
\text { (Dicentrarchus } \\
\text { labrax) }\end{array}$ & $\begin{array}{c}\text { Growth factors } \\
\text { Feeding rates } \\
\text { Gene expression analysis }\end{array}$ & $\begin{array}{l}\text { Results indicated that MPs } \\
\text { inhibit or induce detoxification } \\
\text { in the liver and influence the } \\
\text { lipid distribution } \\
\text { Gene expression results also } \\
\text { indicated that MPs might indeed } \\
\text { potentiate the adverse effect of } \\
\text { some chemical contaminants }\end{array}$ & {$[105$} \\
\hline LD-PE & $\begin{array}{c}125-250 \\
\mu \mathrm{m}\end{array}$ & $\begin{array}{c}\text { Methylmercury } \\
\text { Perfluoroctanesulfona } \\
\text { Perfluorooctanoat } \\
\text { PFOSA } \\
\text { PFNA } \\
\alpha \text {-HBCD } \\
\text { 2,4,6-Tribromphenol } \\
\text { PBDE } 47 \\
\text { PBDE } 99 \\
\text { PBDE } 153 \\
\text { PBDE } 154 \\
\text { PCB } 28 \\
\text { PCB } 52 \\
\text { PCB } 101 \\
\text { PCB } 118 \\
\text { PCB } 138 \\
\text { PCB } 153 \\
\text { PCB } 180\end{array}$ & $\begin{array}{c}\text { Feed A: Basic feed } \\
\text { Feed B: Basic feed }+4 \% \text { of clean } \\
\text { MPs } \\
\text { Feed C: Basic feed }+2 \% \text { of MPs } \\
\text { with sorbed POPs } \\
\text { Feed D: Basic feed + POPs }\end{array}$ & 3 weeks & $\begin{array}{l}\text { Zebrafish } \\
\text { (Danio rerio) }\end{array}$ & $\begin{array}{c}\text { Visual observation (microscopic } \\
\text { level and Hispathological } \\
\text { analysis) } \\
\text { Evaluation of differential gene } \\
\text { expression of some selected } \\
\text { biomarkers }\end{array}$ & $\begin{array}{c}\text { Feed C produced the most } \\
\text { evident effects, especially on the } \\
\text { liver } \\
\text { Combined effects of MPs and } \\
\text { chemicals significantly altered } \\
\text { the homeostasis in greater } \\
\text { manner respect both pollutants } \\
\text { alone }\end{array}$ & [136 \\
\hline LD-PE & $\begin{array}{l}\text { marine } \\
\text { exposition: } \\
3 \mathrm{~mm} \\
\text { feed } \\
\text { exposition: } \\
0.5 \mathrm{~mm}\end{array}$ & $\begin{array}{l}\text { PAHs, PCBs and } \\
\text { PBDEs congeners }\end{array}$ & $\begin{array}{c}\text { Feed A: Basic feed } \\
\text { Feed B: Basic feed + virgin } \\
\text { LD-PE } \\
\text { Feed C: Basic feed + } \\
\text { marine-plastic treatment (LDPE } \\
\text { deployed in San Diego Bay for } 3 \\
\text { months) }\end{array}$ & 2 months & $\begin{array}{c}\text { Japanese } \\
\text { medaka } \\
\text { (Oryzias latipes) }\end{array}$ & $\begin{array}{c}\text { Histopathological analysis } \\
\text { (gonads) } \\
\text { Gene expression analysis on } \\
\text { selected liver's genes and } \\
\text { biomarkers for endocrine } \\
\text { disruption }\end{array}$ & $\begin{array}{l}\text { Results show early- warning } \\
\text { signs of endocrine disruption in } \\
\text { fish exposed to a mixture of } \\
\text { plastic and sorbed contaminants }\end{array}$ & {$[127]$} \\
\hline
\end{tabular}


Table 2. Cont

\begin{tabular}{|c|c|c|c|c|c|c|c|c|}
\hline MP Type & MP Size & Chemical Sorbate & Exposure Concentrations & $\begin{array}{c}\text { Exposure } \\
\text { Time }\end{array}$ & Organism & Toxicological Assessment & Highlight Results & Ref. \\
\hline LD-PE & $\begin{array}{l}\text { marine } \\
\text { exposition: } \\
3 \mathrm{~mm} \\
\text { feed } \\
\text { exposition: } \\
0.5 \mathrm{~mm}\end{array}$ & $\begin{array}{l}\text { PAHs, PCBs and } \\
\text { PBDEs congeners }\end{array}$ & $\begin{array}{c}\text { Feed A: Basic feed } \\
\text { Feed B: Basic feed + virgin } \\
\text { LD-PE } \\
\text { Feed C: Basic feed + } \\
\text { marine-plastic treatment (LDPE } \\
\text { deployed in San Diego Bay for } 3 \\
\text { months) }\end{array}$ & 2 months & $\begin{array}{c}\text { Japanese } \\
\text { medaka } \\
\text { (Oryzias latipes) }\end{array}$ & $\begin{array}{l}\text { Histopathological analysis } \\
\text { (gonads) } \\
\text { Gene expression analysis on } \\
\text { selected liver's genes and } \\
\text { biomarkers for endocrine } \\
\text { disruption }\end{array}$ & $\begin{array}{l}\text { Hepatic stress in medaka } \\
\text { exposed to the combination of } \\
\text { plastic and sorbed contaminants } \\
\text { was demonstrated } \\
\text { No significant differences in the } \\
\text { expression of CYP1A were found } \\
\text { between treatments }\end{array}$ & [31] \\
\hline
\end{tabular}

* Shadowed cells represent environmental relevant concentrations. 
Table 3. Studies assessing the possible synergetic/antagonistic effect of different types of emerging pollutants combined with MPs.

\begin{tabular}{|c|c|c|c|c|c|c|c|c|}
\hline MP Type & MP Size & Chemical Sorbate & Exposure Concentrations & $\begin{array}{l}\text { Exposure } \\
\text { Time }\end{array}$ & Organism & Toxicological Assessment & Highlight Results & Ref. \\
\hline \multicolumn{9}{|c|}{ Pesticides } \\
\hline $\begin{array}{l}\text { HD-PE with } \\
\text { irregular } \\
\text { shape }\end{array}$ & $\begin{array}{l}\text { mean size: } \\
7.73 \mu \mathrm{m}\end{array}$ & Chlorpyrifos (CPF) & 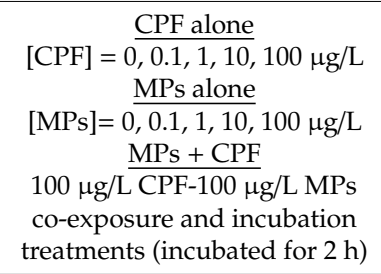 & $48 \mathrm{~h}$ & $\begin{array}{l}\text { Marine copepod } \\
(\text { Acartia tonsa })\end{array}$ & $\begin{array}{l}\text { The survival rates } \\
\text { Fecundity, feeding and egg } \\
\text { viability }\end{array}$ & $\begin{array}{l}\text { CPF showed higher toxicity } \\
\text { when combined with MP than } \\
\text { alone for all tested biological } \\
\text { responses } \\
\text { Higher toxicity was observed } \\
\text { with the co-exposure treatment }\end{array}$ & [137] \\
\hline PE & $\begin{array}{l}\text { mean size: } \\
\text { ranging } \\
\text { from } 2-6 \\
\mu \mathrm{m} \\
\text { maximum } \\
\text { particle } \\
\text { size: } \\
22 \mu \mathrm{m}\end{array}$ & Chlorpyrifos & $\begin{array}{c}\text { CPF alone } \\
{[\mathrm{CPF}]=0 \text { to } 4 \mathrm{mg} / \mathrm{L}} \\
\text { MPs alone } \\
{[\mathrm{MPs}]=0.5,1,10 \text { and } 25 \mathrm{mg} / \mathrm{L}} \\
\mathrm{MPs}+\mathrm{CPF}(\text { co-exposure) } \\
0-3 \mathrm{mg} / \mathrm{L} \mathrm{CPF}-1 \mathrm{mg} / \mathrm{L} \mathrm{MPs} \\
\text { co-exposure and incubation } \\
\text { treatments (incubated for } 2 \mathrm{~h} \text { ) }\end{array}$ & $72 \mathrm{~h}$ & $\begin{array}{l}\text { Microalgae } \\
\text { (Isochrysis } \\
\text { galbana } \\
\text { clone T-ISO) }\end{array}$ & $\begin{array}{l}\text { Microalgae daily growth rate } \\
\text { Inhibition of microalgae growth }\end{array}$ & $\begin{array}{l}\text { MPs reduced the toxicity of CPF } \\
\text { MPs were not small enough to } \\
\text { penetrate the microalgal cell and } \\
\text { cause any damage }\end{array}$ & [138] \\
\hline PS & $\begin{array}{c}0.1 \mathrm{~mm}, \\
0.55 \mathrm{~mm} \\
5 \mathrm{~mm}\end{array}$ & $\begin{array}{l}\text { Triphenyltin } \\
\text { chloride (TPTCl) }\end{array}$ & $\begin{array}{c}\text { TPTCl alone } \\
{[\mathrm{TPTCl}=30 \mu \mathrm{g} / \mathrm{L}} \\
\text { MPs alone } \\
{[\mathrm{MPs}]=0.05,0.5,5 \mathrm{mg} / \mathrm{L}} \\
\text { MPs }+ \text { TPTCl } \\
\begin{array}{c}\text { Combination of the individual } \\
\text { concentrations tested for both } \\
\text { pollutants }\end{array}\end{array}$ & $96 \mathrm{~h}$ & $\begin{array}{l}\text { Microalgae } \\
\text { (Chlorella } \\
\text { pyrenoidosa) }\end{array}$ & $\begin{array}{l}\text { Morphology and structural } \\
\text { damage } \\
\text { Grown inhibition }\end{array}$ & $\begin{array}{l}\text { PS particles toxicity to the green } \\
\text { algae was size-dependent } \\
\text { Toxicity of the mixture was } \\
\text { size-dependent: MPs with } \\
\text { smaller particle size increased } \\
\text { the toxicity of TPTCl }\end{array}$ & [139] \\
\hline Pristine PE & $10-27 \mu \mathrm{m}$ & Bifenthrin & $\begin{array}{c}\text { Bifenthrin alone } \\
\text { [Bifenthrin] }=0.1 \text { to } 3.2 \mu \mathrm{g} / \mathrm{L} \\
\text { MPs alone } \\
{[\mathrm{MPs}]=5 \mathrm{mg} / \mathrm{L}} \\
\text { MPs+ Bifentrin (co-exposure) } \\
0.1-3.2 \mu \mathrm{g} / \mathrm{L} \mathrm{CPF}-5 \mathrm{mg} / \mathrm{L} \mathrm{MPs}\end{array}$ & $48 \mathrm{~h}$ & $\begin{array}{l}\text { Freshwater } \\
\text { larvae organism } \\
\text { (Chironomus } \\
\text { tepperi) }\end{array}$ & Immobilization rates & $\begin{array}{c}\text { The addition of MPs to synthetic } \\
\text { water reduced the toxicity of } \\
\text { bifenthrin } \\
\text { The addition of MPs to river } \\
\text { water did not mitigate bifenthrin } \\
\text { toxicity due to the greater } \\
\text { interaction of bifenthrin with } \\
\text { DOM }\end{array}$ & [140] \\
\hline
\end{tabular}


Table 3. Cont

\begin{tabular}{|c|c|c|c|c|c|c|c|c|}
\hline MP Type & MP Size & Chemical Sorbate & Exposure Concentrations & $\begin{array}{c}\text { Exposure } \\
\text { Time }\end{array}$ & Organism & Toxicological Assessment & Highlight Results & Ref. \\
\hline $\begin{array}{l}\text { PET/PA } \\
\text { fibers }\end{array}$ & $\begin{array}{l}\text { length: } \\
10 \mu \mathrm{m} \\
\text { width: } \\
2 \mu \mathrm{m}\end{array}$ & $\begin{array}{l}\text { Three different } \\
\text { glyphosate } \\
\text { chemical } \\
\text { formulations }\end{array}$ & $\begin{array}{c}\text { Glyphosate alone } \\
\text { [Glyphosate] }=2.5 \mathrm{mg} / \mathrm{L} \\
\text { PE alone } \\
\text { [MPs]=0.01 mg/mL } \\
\text { Fibers alone } \\
\text { [MPs]=0.045-0.136 } \mu \mathrm{g} / \mathrm{L} \\
\text { MPs + glyphosate } \\
\text { Single treatments were combined }\end{array}$ & 1 week & Daphnia magna & Mortality rate & $\begin{array}{l}\text { The toxicity of the mixture was } \\
\text { more influenced by the type and } \\
\text { size of the MPs than their } \\
\text { abundance } \\
\text { Toxicity of glyphosate was } \\
\text { enhanced by the presence of MPs }\end{array}$ & [141] \\
\hline PS & $1 \mu \mathrm{m}$ & $\begin{array}{l}\text { Dimetholate } \\
\text { Deltamethrin }\end{array}$ & $\begin{array}{c}\text { Pesticides alone } \\
\text { [Dimetholate] }=0.156,0.313, \\
0.625,1.25 \text { and } 5 \mathrm{mg} / \mathrm{L} \\
\text { [Deltamethrin]: } 0.016,0.08,0.4 \\
2,5,10 \mu \mathrm{g} / \mathrm{L} \\
\quad \text { MPs alone } \\
\text { [MPs] }=300,000 \text { particles } / \mathrm{mL} \\
\text { MPs + glyphosate } \\
\text { Single treatments were combined }\end{array}$ & $72 \mathrm{~h}$ & Daphnia magna & $\begin{array}{l}\text { Mortality rate } \\
\text { Impaired mobility }\end{array}$ & $\begin{array}{l}\text { The concentrations at which } \\
\text { detrimental effects occurred were } \\
\text { not influenced by the presence of } \\
\text { MPs }\end{array}$ & [142] \\
\hline \multicolumn{9}{|c|}{ Pharmaceuticals } \\
\hline PE & $1-5 \mu \mathrm{m}$ & Cefalexin & $\begin{array}{c}\frac{\text { Cefalexin alone }}{\text { [Cefalexin] }=1.3,2.5,5 \text { and } 10} \\
\mathrm{mg} / \mathrm{L} \\
\text { MPs alone } \\
\text { [MPs]=0.184 mg/L } \\
\text { MPs + Cefalexin } \\
\text { Combination of individual } \\
\text { exposure concentrations } \\
\text { (Exposure experiments } \\
\text { performed at } 20 \text { and } 25^{\circ} \mathrm{C} \text { ) }\end{array}$ & $96 \mathrm{~h}$ & $\begin{array}{l}\text { Common goby } \\
\text { juveniles } \\
\text { (Pomatoschistus } \\
\text { microps) }\end{array}$ & $\begin{array}{c}\text { Mortality rate } \\
\text { Post-predatory performance } \\
\text { AChE activity } \\
\text { LPO levels }\end{array}$ & $\begin{array}{l}\text { The temperature rise increased } \\
\text { the toxicity for both pollutants } \\
\text { alone and in MPs mix } \\
\text { No significant differences } \\
\text { between cefalexin treatment } \\
\text { alone and in MPs mix }\end{array}$ & [143] \\
\hline PE & $10-90 \mu \mathrm{m}$ & Triclosan & $\begin{array}{c}\text { Triclosan alone } \\
\text { [Triclosan] }=0-300 \mu \mathrm{g} / \mathrm{L} \\
\text { MPs alone } \\
{[\mathrm{MPs}]=0-25,000 \mathrm{MPs} / \mathrm{mL}} \\
\text { MPs+ Cefalexin } \\
\text { Combination of individual } \\
\text { exposure concentrations of } \\
\text { Triclosan and } 500 \mathrm{MPs} / \mathrm{mL}\end{array}$ & $48 \mathrm{~h}$ & $\begin{array}{l}\text { Marine copepod } \\
\text { (Acartia tonsa) }\end{array}$ & Mortality of marine copepods & $\begin{array}{l}\text { The LC50-values of individual } \\
\text { pollutants and mixture were } \\
\text { significantly different } \\
\text { (synergistic effect) }\end{array}$ & [144] \\
\hline
\end{tabular}


Table 3. Cont.

\begin{tabular}{|c|c|c|c|c|c|c|c|c|}
\hline MP Type & MP Size & Chemical Sorbate & Exposure Concentrations & $\begin{array}{c}\text { Exposure } \\
\text { Time }\end{array}$ & Organism & Toxicological Assessment & Highlight Results & Ref. \\
\hline PS & $\begin{array}{c}1 \mu \mathrm{m} \\
10 \mu \mathrm{m}\end{array}$ & $\begin{array}{l}\text { Roxithromycin } \\
\text { (ROX) }\end{array}$ & 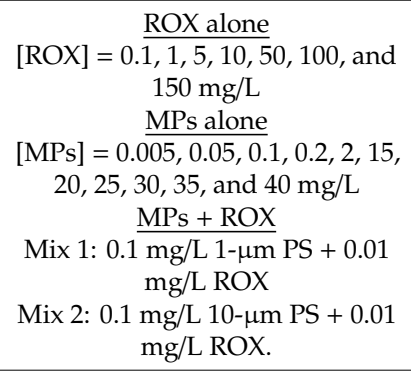 & $48 \mathrm{~h}$ & Daphnia magna & $\begin{array}{c}\text { Mortality rate } \\
\text { MDA levels } \\
\text { Activities of: SOD, CAT, GST } \\
\text { and GPx }\end{array}$ & $\begin{array}{l}\text { Small-size PS was more toxic to } \\
\text { D. magna than the large-size PS } \\
\text { Co-exposure to 1- } \mu \mathrm{m} \text { PS and } \\
\text { ROX led to the strongest } \\
\text { biological responses in D. magna }\end{array}$ & [6] \\
\hline PS & $0.1 \mu \mathrm{m}$ & $\begin{array}{l}\text { Roxithromycin } \\
\text { (ROX) }\end{array}$ & $\begin{array}{c}\frac{\text { Roxithromycin alone }}{[\mathrm{ROX}]=50 \mu \mathrm{g} / \mathrm{L}} \\
\mathrm{MPs}+\mathrm{ROX} \\
\text { Mix 1: } 1 \mu \mathrm{g} / \mathrm{L} \mathrm{MPs}+50 \mu \mathrm{g} / \mathrm{L} \text { ROX } \\
\text { Mix 2: } 10 \mu \mathrm{g} / \mathrm{L} \mathrm{MPs}+50 \mu \mathrm{g} / \mathrm{L} \\
\text { ROX. } \\
\text { Mix 3: } 100 \mu \mathrm{g} / \mathrm{L} \mathrm{MPs}+50 \mu \mathrm{g} / \mathrm{L} \\
\text { ROX. }\end{array}$ & 14 days & $\begin{array}{l}\text { Water fish red } \\
\text { tilapia } \\
\text { (Oreochromis } \\
\text { niloticus) }\end{array}$ & $\begin{array}{l}\text { Histopathological analysis (liver, } \\
\text { gills, guts and brain) } \\
\text { AChE, EROD, BFCOD, SOD and } \\
\text { MDA activities }\end{array}$ & $\begin{array}{l}\text { The neurotoxicity caused by } \\
\text { ROX was alleviated due to the } \\
\text { presence of MPs } \\
\text { The presence of MPs may affect } \\
\text { the metabolism of ROX in tilapia } \\
\text { Oxidative damage in situations } \\
\text { of co-exposure to MPs and ROX } \\
\text { was mitigated in fish livers } \\
\text { This study suggests that the } \\
\text { effects of MPs combined with } \\
\text { other pollutants cannot be } \\
\text { ignored }\end{array}$ & [109] \\
\hline unknown & $1-5 \mu \mathrm{m}$ & Florfenicol & $\begin{array}{c}\text { Florfenicol alone } \\
\text { [Florfenicol] }=1.8 \text { and } 7.1 \mathrm{mg} / \mathrm{L} \\
\text { MPs alone } \\
{[\mathrm{MPs}=0.2 \text { and } 0.7 \mathrm{mg} / \mathrm{L}} \\
\text { MPs + Florfenicol } \\
\text { Combination of individual } \\
\text { exposure concentrations of both } \\
\text { pollutants }\end{array}$ & $96 \mathrm{~h}$ & $\begin{array}{l}\text { Marine bivalve } \\
\text { (Corbicula } \\
\text { fluminea) }\end{array}$ & $\begin{array}{c}\text { Feeding inhibition } \\
\text { Histopathological alterations } \\
\text { (digestive system and gills) } \\
\text { Enzymatic activities of ChE, IDH, } \\
\text { ODH, GST, GR, GPx and } \\
\text { CATLPO levels }\end{array}$ & $\begin{array}{l}\text { Enhanced toxicity of florfenicol } \\
\text { in combination with MPs } \\
\text { Differences in the toxicological } \\
\text { effects induced by mixtures } \\
\text { containing the lowest or the } \\
\text { highest concentrations of both } \\
\text { substances }\end{array}$ & [48] \\
\hline
\end{tabular}


Table 3. Cont

\begin{tabular}{|c|c|c|c|c|c|c|c|c|}
\hline MP Type & MP Size & Chemical Sorbate & Exposure Concentrations & $\begin{array}{c}\text { Exposure } \\
\text { Time }\end{array}$ & Organism & Toxicological Assessment & Highlight Results & Ref. \\
\hline PVC & $<10 \mu \mathrm{m}$ & $\begin{array}{c}\text { Venlafaxine } \\
\text { O-desmethylvenlafaxine }\end{array}$ & $\begin{array}{c}\frac{\text { Venlafaxine and derivate alone }}{\text { [Venlafaxine] }=0-500 \mu \mathrm{g} / \mathrm{L}} \\
\text { O-desmethylvenlafaxine alone } \\
{[\text { O-desmethylvenlafaxine] }=} \\
0-500 \mu \mathrm{g} / \mathrm{L} \\
\text { MPs }+ \text { chemicals } \\
\text { Combination of individual } \\
\text { exposure concentrations of both } \\
\text { pollutants and } 50 \mathrm{mg} / \mathrm{L} \text { of MPs }\end{array}$ & 4 days & $\begin{array}{c}\text { Loach } \\
\text { (Misgurnus } \\
\text { anguillicaudatus) }\end{array}$ & SOD and MDA activities & $\begin{array}{l}\text { In liver subcellular structure, } \\
\text { MPs may help to transport } \\
\text { pollutants into subtle areas and } \\
\text { postpone the contaminants } \\
\text { metabolism } \\
\text { Mixtures enhance the oxidative } \\
\text { stress in loach } \\
\text { Enantioselective effects were } \\
\text { observed in high dose exposure } \\
\text { groups } \\
\text { MPs combined with chemicals } \\
\text { might cause more adverse effects } \\
\text { to organisms compared with } \\
\text { only chemicals themselves. }\end{array}$ & [110] \\
\hline unknown & $1-5 \mu \mathrm{m}$ & $\begin{array}{l}\text { Procainamide } \\
\text { Doxycycline }\end{array}$ & $\begin{array}{c}\text { Procainamide alone } \\
\text { [Procainamide] }=4,8,16,32,64, \\
128 \text { and } 256 \mathrm{mg} / 1 \\
\text { Doxycycline alone } \\
\text { [Doxicycline] }=4,8,16,32,64 \\
\text { and } 128 \mathrm{mg} / \mathrm{l} \\
\text { MPs alone } \\
{[\mathrm{MPs}]=0.75,1.5,3,6,12,24 \text { and }} \\
48 \mathrm{mg} / \mathrm{l} \\
\text { MPs }+ \text { chemicals } \\
\text { Combination of individual } \\
\text { exposure concentrations of both } \\
\text { chemicals and } 1.5 \mathrm{mg} / \mathrm{L} \text { of MPs }\end{array}$ & $96 \mathrm{~h}$ & $\begin{array}{l}\text { Marine } \\
\text { microalga } \\
\text { (Tetraselmis } \\
\text { chuii) }\end{array}$ & $\begin{array}{c}\text { Inhibition of average specific } \\
\text { grow per day } \\
\text { Chlorophyll concentration } \\
\text { decrease }\end{array}$ & $\begin{array}{l}\text { Significant toxicity enhancement } \\
\text { of each pharmaceutical in } \\
\text { mixture with MPs was found for } \\
\text { procainamide (chlorophyll), and } \\
\text { doxycycline (both parameters) }\end{array}$ & [145] \\
\hline PS & $\begin{array}{c}30 \mu \mathrm{m} \\
500 \mathrm{~nm}\end{array}$ & Sertraline (Ser) & $\begin{array}{c}\text { Ser. alone } \\
\text { [Ser]=100ng } / \mathrm{L} \\
\text { MPs alone } \\
{[\mathrm{MPs}]=0.29 \mathrm{mg} / \mathrm{L}} \\
\text { MPs }+ \text { Ser. } \\
\text { Combination of individual } \\
\text { exposure concentrations of both } \\
\text { pollutants }\end{array}$ & 14 days & $\begin{array}{l}\text { Bivalve mollusk } \\
\text { (Tegillarca } \\
\text { granosa) }\end{array}$ & $\begin{array}{c}\text { ROS generation } \\
\text { Apoptosis status } \\
\text { MDA, ACh and GABA levels } \\
\text { Plama cortisol content } \\
\text { ATP content and PK activity } \\
\text { Transcriptomic analysis }\end{array}$ & $\begin{array}{c}\text { Evident synergistic } \\
\text { immuno-toxic effect was } \\
\text { observed between Ser. and NPs } \\
\text { NPs could exert more toxic } \\
\text { effects than larger MPs }\end{array}$ & [146] \\
\hline
\end{tabular}


Table 3. Cont

\begin{tabular}{|c|c|c|c|c|c|c|c|c|}
\hline MP Type & MP Size & Chemical Sorbate & Exposure Concentrations & $\begin{array}{l}\text { Exposure } \\
\text { Time }\end{array}$ & Organism & Toxicological Assessment & Highlight Results & Ref. \\
\hline \multicolumn{9}{|c|}{ Others (UV Filters, Surfactants, Plasticizers, ... ) } \\
\hline $\begin{array}{l}\text { PE irregular } \\
\text { shape }\end{array}$ & $\begin{array}{l}3.4 \mu \mathrm{m} \\
9.9 \mu \mathrm{m}\end{array}$ & $\begin{array}{c}\text { 4-Nonylphenol } \\
\text { (4-NP) } \\
\text { 4- MBC }\end{array}$ & $\begin{array}{c}\text { 4-NP alone } \\
{[4-\mathrm{NP}]=4,25 \text { and } 70 \mu \mathrm{g} / \mathrm{l}} \\
\text { 4-Nonyphenol alone } \\
{[4-\mathrm{MBC}]=70,150 \text { and } 350 \mu \mathrm{g} / \mathrm{l}} \\
\text { MPs }+ \text { chemicals } \\
\text { Combination of individual } \\
\text { exposure concentrations of both } \\
\text { chemicals with } 1 \text { and } 10 \mathrm{mg} / \mathrm{L} \text { of } \\
\text { MPs }\end{array}$ & $48 \mathrm{~h}$ & $\begin{array}{c}\text { Marine } \\
\text { zooplanktons }\end{array}$ & $\begin{array}{c}\text { Effective concentration reducing } \\
\text { the larval size } \\
\text { Mortality rate }\end{array}$ & $\begin{array}{l}\text { The presence of MPs did not } \\
\text { increase the toxicity of both } \\
\text { chemicals tested }\end{array}$ & [111] \\
\hline $\begin{array}{l}\text { PE irregular } \\
\text { shape }\end{array}$ & $\begin{array}{l}3.4 \mu \mathrm{m} \\
9.9 \mu \mathrm{m}\end{array}$ & $\begin{array}{l}\text { 4-Nonylphenol } \\
\text { (4-NP) }\end{array}$ & $\begin{array}{c}\text { 4-NP alone } \\
{[4-\mathrm{NP}]=20 \text { and } 60 \mu \mathrm{g} / \mathrm{l}} \\
\text { MPs }+4-\mathrm{NP} \\
\text { Combination of individual } \\
\text { exposure concentrations of } 4-\mathrm{NP} \\
\text { with } 1 \text { and } 10 \mathrm{mg} / \mathrm{L} \text { of MPs }\end{array}$ & $48 \mathrm{~h}$ & $\begin{array}{l}\text { Planktonic } \\
\text { sea-urchin } \\
\text { larvae }\end{array}$ & $\begin{array}{l}\text { Filtering rate } \\
\text { Effective concentration reducing } \\
\text { larval growth }\end{array}$ & $\begin{array}{l}\text { The ingestion of MPs did not } \\
\text { increase the toxicity of 4-NP }\end{array}$ & [147] \\
\hline PE & $50 \mathrm{~nm}$ & BPA & 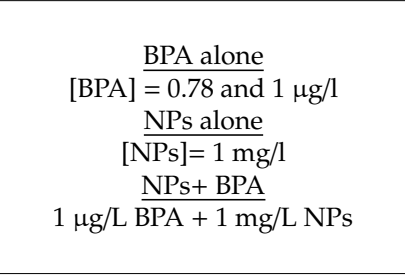 & 3 days & $\begin{array}{l}\text { Zebrafish } \\
\text { (Danio rerio) }\end{array}$ & $\begin{array}{c}\text { Gene expression analysis } \\
\text { AChE activity } \\
\text { Dopamine level } \\
\text { Protein content }\end{array}$ & $\begin{array}{l}\text { The co-exposure of NPs and BPA } \\
\text { led to increased neurotoxic } \\
\text { effects in both CNS and } \\
\text { dopaminergic system } \\
\text { The reduction of the AChE } \\
\text { activity in co-exposure treatment } \\
\text { was alleviated in comparison to } \\
\text { single experiments }\end{array}$ & [113] \\
\hline PS & $\begin{array}{l}0.1 \mathrm{~mm} \\
0.55 \mathrm{~mm} \\
5 \mathrm{~mm}\end{array}$ & $\begin{array}{l}\text { Dibutyl phthalate } \\
\text { (DBP) }\end{array}$ & $\begin{array}{c}\text { DBP alone } \\
{[\mathrm{DBP}]=0.25,0.5,1,2,4,8 \text { and } 16} \\
\mathrm{mg} / \mathrm{l} \\
\text { MPs alone } \\
{[\mathrm{MPs}]=0.5,1,2,4,8,16,32 \text { and }} \\
64 \mathrm{mg} / \mathrm{l} \\
\text { MPs + BPA } \\
\text { Combination of individual } \\
\text { exposure concentrations of both } \\
\text { pollutants (MPs size: } 0.1 \mathrm{~mm} \text { ) }\end{array}$ & $96 \mathrm{~h}$ & $\begin{array}{l}\text { Microalgae } \\
\text { (Chlorella } \\
\text { pyrenoidosa) }\end{array}$ & $\begin{array}{l}\text { Grow inhibition rate } \\
\text { Changes in morphology and } \\
\text { structural damage } \\
\text { Chlorophyll levels }\end{array}$ & $\begin{array}{l}\text { The interaction between MPs } \\
\text { and DBP was antagonistic at low } \\
\text { concentrations of DBP } \\
\text { Synergistic effect was found at } \\
\text { relatively high concentrations of } \\
\text { DBP when }[\mathrm{MPs}]<10 \mathrm{mg} / \mathrm{L} \\
\text { Antagonistic effect was found } \\
\text { across all concentrations of MPs } \\
\text { above } 10 \mathrm{mg} / \mathrm{L}\end{array}$ & [148] \\
\hline
\end{tabular}


Table 3. Cont

\begin{tabular}{|c|c|c|c|c|c|c|c|c|}
\hline MP Type & MP Size & Chemical Sorbate & Exposure Concentrations & $\begin{array}{l}\text { Exposure } \\
\text { Time }\end{array}$ & Organism & Toxicological Assessment & Highlight Results & Ref. \\
\hline Flexible PVC & $12-276 \mu \mathrm{m}$ & $\begin{array}{l}\text { Diisononylphthalate } \\
\text { (DiNP) }\end{array}$ & $\begin{array}{c}\text { Rigid PVC (PVC) } \\
4320 \mathrm{MP} \text { particles } / 100 \mathrm{~mL} \\
\text { Flexible PVC with DiNP } \\
4320 \text { particles } / 100 \mathrm{~mL} \\
\text { ([DiNP] in PVC was } 30 \% \text { of } \\
\text { plastic weight) }\end{array}$ & 25-31 days & Daphnia magna & $\begin{array}{c}\text { Mortality rate } \\
\text { Morphology changes and body } \\
\text { length } \\
\text { Reproductive output }\end{array}$ & $\begin{array}{c}\text { MPs containing DiNP } \\
\text { significantly affect the number of } \\
\text { offspring as well as the growth of } \\
\text { D. magna } \\
\text { The relevance of long-term } \\
\text { chronic exposure experiments, as } \\
\text { effects did emerge relatively late } \\
\text { in the experiment }\end{array}$ & [149] \\
\hline
\end{tabular}

*Shadowed cells represent environmental relevant concentrations. 
Considering the variety of studied chemicals, PAHs, PCBs and metals interaction with MPs and NPs are the most usual studies. Besides, the combined toxicity of MPs with emerging pollutants (mainly PhACs) has increased in recent years. However, it is important to remark that the assessment of the synergetic or antagonistic toxic effects of environmental pollutants combined with MPs using a mixture of chemicals may be the key to understand the actual toxicity of MPs. The sorption enhancement or decline of chemicals in the MPs matrix in addition to the different interaction mechanisms with biota would provide more realistic conclusions. Thus, the approaches performed by Rochman et al. [31,127], Granby et al. [105] or Rainieri et al. [136] should be adopted where possible in future researches.

It is also essential to keep in mind that there are different ways to evaluate the combined effects of chemical pollutants and MPs. On the one hand, the majority of works have studied the combined toxicological impact by performing a co-exposure of both pollutants. On the other hand, other studies have tested the combined toxicity carrying out a previous incubation step. Consequently, these studies also allow the assessment of the possible desorption of pollutants from the MPs. For this reason, this kind of studies could be especially important for those chemicals commonly related to plastic compounds. For instance, the combined effects of MPs with plasticizers such as BPA, TBBPA or dibutyl phthalate should also be performed by adding a previous incubation step. Therefore, these toxicological studies would model better the real scenarios as those compounds could also be leached from the MPs matrix and surface.

Regarding the analysed toxicological parameters, most of them are related to the evaluation of acute toxicity. For instance, survival rate, post-predatory performance or grown inhibition are the most used. In addition, biomarkers evaluation (e.g., changes of $\mathrm{AChE}$, glutathione (GSH), SOD, malondialdehyde (MDA)) is also widely performed. However, future studies should also integrate the information coming from different omic technologies (e.g., transcriptomics, metabolomics) to understand the changes caused by the interaction of MPs and pollutants at a molecular level. Besides, the use of these multi-omics approaches may also be of great help to achieve a holistic view of the whole biological picture. These multi-omics studies are suitable for the confirmation of the causal relationship and association between environmental exposure and pathogenesis, by assessing multiple aspects following the omics cascade: mutations in the DNA sequence may induce changes in the degree of epigenetic regulation, which might alter gene expression and, consequently, protein expression, leading eventually to a metabolomics effect [150].

Author Contributions: Conceptualization: A.M.-P. and J.J.; Writing-Original Draft Preparation, A.M.-P.; Writing-Review \& Editing, J.J.; funding acquisition: J.J. All authors have read and agreed to the published version of the manuscript.

Funding: The research leading to these results has received funding from the Spanish Ministry of Science and Innovation (MCI, Grant CTQ2017-82598-P). The authors also want to grant support from the Catalan Agency for Management of University and Research Grants (AGAUR, Grant 2017SGR753) and the Spanish MCI (Severo Ochoa Project CEX2018-000794-S). AMP also acknowledges a JAE-Intro fellowship from the Spanish National Research Council (CSIC).

Conflicts of Interest: The authors declare no conflict of interest. 
Abbreviations:

$\begin{array}{ll}\text { 4-MBC } & \text { 4-Methylbenzylidene-camphor } \\ \text { AChE } & \text { Acetylcholinesterase } \\ \text { BPA } & \text { Bisphenol A } \\ \text { DDTs } & \text { Dichlorobiphenyl Trichloroethanes } \\ \text { DOM } & \text { Dissolved Organic Matter } \\ \text { EROD } & \text { 7-ethoxyresorufin O-deethylase } \\ \text { GSH } & \text { Glutathione } \\ \text { HCHs } & \text { Hexachlorocyclohexanes } \\ \text { HDPE } & \text { High-Density Polyethylene } \\ \text { HOCs } & \text { Hydrophobic Organic Compounds } \\ \text { Kow } & \text { Octanol-water partition coefficient } \\ \text { Kpw } & \text { Plastic-water partition coefficient } \\ \text { LDPE } & \text { Low-Density Polyethylene } \\ \text { LPO } & \text { Lipid Peroxidation } \\ \text { MDA } & \text { Malondialdehyde } \\ \text { MPs } & \text { Microplastics } \\ \text { MTLP } & \text { Metallothionein-like Proteins } \\ \text { NOAA } & \text { US National Oceanographic and Atmospheric Administration } \\ \text { NPs } & \text { Nanoplastics } \\ \text { NSAID } & \text { Nonsteroidal Anti-inflammatory Drugs } \\ \text { OPFRs } & \text { Organophosphorus Flame-Retardants } \\ \text { PA } & \text { Polyamide } \\ \text { PAHs } & \text { Polycyclic Aromatic Hydrocarbons } \\ \text { PBDEs } & \text { Polybrominated Diphenyl Ethers } \\ \text { PCBs } & \text { Polychlorinated Biphenyls } \\ \text { PE } & \text { Polyethylene } \\ \text { PET } & \text { Polyethylene Terephthalate } \\ \text { PFAS } & \text { Perfluoroalkyl substances } \\ \text { PFNA } & \text { Perfluornonanoic Acid } \\ \text { PFOS } & \text { Perfluorooctanesulfonate } \\ \text { PFOSA } & \text { Perfluorooctanesulfonamide } \\ \text { PhACs } & \text { Pharmaceuticals Active Compounds } \\ \text { POPs } & \text { Persistent Organic Pollutants } \\ \text { PP } & \text { Polypropylene } \\ \text { PTFE } & \text { Polytetrafluoroethylene } \\ \text { PVC } & \text { Polyvinyl Chloride } \\ \text { SOD } & \text { Superoxide Dismutase } \\ \text { TBBPA } & \text { Tetrabromobisphenol A } \\ \text { Tg } & \text { Glass Transition Temperature } \\ & \end{array}$

\section{References}

1. Plastics-The Facts 2019. Available online: https://www.plasticseurope.org/es/resources/publications/1804plastics-facts-2019 (accessed on 19 December 2019).

2. Geyer, R.; Jambeck, J.R.; Law, K.L. Production, use, and fate of all plastics ever made. Sci. Adv. 2017, 3, 25-29. [CrossRef] [PubMed]

3. Li, M.; Peng, J.; Qiu, Q.; Zhan, Z.; Wang, J.; Tan, Z. Extraction, enumeration and identification methods for monitoring microplastics in the environment. Estuar. Coast. Shelf Sci. 2016, 176, 102-109. [CrossRef]

4. Silva, A.B.; Bastos, A.S.; Justino, C.I.L.; da Costa, J.P.; Duarte, A.C.; Rocha-Santos, T.A.P. Microplastics in the environment: Challenges in analytical chemistry-A review. Anal. Chim. Acta 2018, 1017, 1-19. [CrossRef] [PubMed] 
5. Magara, G.; Khan, F.R.; Pinti, M.; Syberg, K.; Inzirillo, A.; Elia, A.C. Effects of combined exposures of fluoranthene and polyethylene or polyhydroxybutyrate microplastics on oxidative stress biomarkers in the blue mussel (Mytilus edulis). J. Toxicol. Environ. Health-Part A Curr. Issues 2019, 82, 616-625. [CrossRef] [PubMed]

6. Zhang, P.; Yan, Z.; Lu, G.; Ji, Y. Single and combined effects of microplastics and roxithromycin on Daphnia magna. Environ. Sci. Pollut. Res. 2019, 26, 17010-17020. [CrossRef] [PubMed]

7. Sıkdokur, E.; Belivermiş, M.; Sezer, N.; Pekmez, M.; Bulan, Ö.K.; Kılıç, Ö. Effects of microplastics and mercury on manila clam Ruditapes philippinarum: Feeding rate, immunomodulation, histopathology and oxidative stress. Environ. Pollut. 2020, 262, 114247. [CrossRef]

8. Tang, Y.; Rong, J.; Guan, X.; Zha, S.; Shi, W.; Han, Y.; Du, X.; Wu, F.; Huang, W.; Liu, G. Immunotoxicity of microplastics and two persistent organic pollutants alone or in combination to a bivalve species. Environ. Pollut. 2020, 258, 113845. [CrossRef]

9. Avio, C.G.; Gorbi, S.; Regoli, F. Plastics and microplastics in the oceans: From emerging pollutants to emerged threat. Mar. Environ. Res. 2017, 128, 2-11. [CrossRef]

10. GESAMP. Sources, Fate and Effects of Microplastics in the Marine Environment: A Global Assessment; Kershaw, P.J., Ed.; IMO/FAO/UNESCO-IOC/UNIDO/WMO/IAEA/UN/UNEP/UNDP Joint Group of Experts on the Scientific Aspects of Marine Environment Protection; Reports Stud. GESAMP; GESAMP: London, UK, 2015; Volume 90, pp. 1-96. [CrossRef]

11. Auta, H.S.; Emenike, C.U.; Fauziah, S.H. Distribution and importance of microplastics in the marine environmentA review of the sources, fate, effects, and potential solutions. Environ. Int. 2017, 102, 165-176. [CrossRef]

12. Li, J.; Liu, H.; Paul Chen, J. Microplastics in freshwater systems: A review on occurrence, environmental effects, and methods for microplastics detection. Water Res. 2018, 137, 362-374. [CrossRef]

13. Boucher, J.; Friot, D. Primary Microplastics in the Oceans: A Global Evaluation of Sources; IUCN: Gland, Switzerland, 2017; ISBN 9782831718279.

14. Andrady, A.L. Microplastics in the marine environment. Mar. Pollut. Bull. 2011, 62, 1596-1605. [CrossRef] [PubMed]

15. Lusher, A.L.; Tirelli, V.; O'Connor, I.; Officer, R. Microplastics in Arctic polar waters: The first reported values of particles in surface and sub-surface samples. Sci. Rep. 2015, 5, 1-9. [CrossRef] [PubMed]

16. Ruiz-Orejón, L.F.; Sardá, R.; Ramis-Pujol, J. Now, you see me: High concentrations of floating plastic debris in the coastal waters of the Balearic Islands (Spain). Mar. Pollut. Bull. 2018, 133, 636-646. [CrossRef] [PubMed]

17. Claessens, M.; Meester, S.; De Landuyt, L.; Van Clerck, K.; De Janssen, C.R. Occurrence and distribution of microplastics in marine sediments along the Belgian coast. Mar. Pollut. Bull. 2011, 62, 2199-2204. [CrossRef] [PubMed]

18. Lusher, A.L.; Burke, A.; O'Connor, I.; Officer, R. Microplastic pollution in the Northeast Atlantic Ocean: Validated and opportunistic sampling. Mar. Pollut. Bull. 2014, 88, 325-333. [CrossRef]

19. Ma, H.; Pu, S.; Liu, S.; Bai, Y.; Mandal, S.; Xing, B. Microplastics in aquatic environments: Toxicity to trigger ecological consequences. Environ. Pollut. 2020, 261, 114089. [CrossRef] [PubMed]

20. Lehtiniemi, M.; Hartikainen, S.; Näkki, P.; Engström-Öst, J.; Koistinen, A.; Setälä, O. Size matters more than shape: Ingestion of primary and secondary microplastics by small predators. Food Webs 2018, 17, e00097. [CrossRef]

21. Moore, C.J.; Moore, S.L.; Leecaster, M.K.; Weisberg, S.B. A comparison of plastic and plankton in the North Pacific Central Gyre. Mar. Pollut. Bull. 2001, 42, 1297-1300. [CrossRef]

22. Fossi, M.C.; Coppola, D.; Baini, M.; Giannetti, M.; Guerranti, C.; Marsili, L.; Panti, C.; de Sabata, E.; Clò, S. Large filter feeding marine organisms as indicators of microplastic in the pelagic environment: The case studies of the Mediterranean basking shark (Cetorhinus maximus) and fin whale (Balaenoptera physalus). Mar. Environ. Res. 2014, 100, 17-24. [CrossRef]

23. Cole, M.; Lindeque, P.; Fileman, E.; Halsband, C.; Goodhead, R.; Moger, J.; Galloway, T.S. Microplastic ingestion by zooplankton. Environ. Sci. Technol. 2013, 47, 6646-6655. [CrossRef]

24. Sun, X.; Li, Q.; Zhu, M.; Liang, J.; Zheng, S.; Zhao, Y. Ingestion of microplastics by natural zooplankton groups in the northern South China Sea. Mar. Pollut. Bull. 2017, 115, 217-224. [CrossRef] [PubMed]

25. Ivar Do Sul, J.A.; Costa, M.F. The present and future of microplastic pollution in the marine environment. Environ. Pollut. 2014, 185, 352-364. [CrossRef] 
26. Gonçalves, C.; Martins, M.; Sobral, P.; Costa, P.M.; Costa, M.H. An assessment of the ability to ingest and excrete microplastics by filter-feeders: A case study with the Mediterranean mussel. Environ. Pollut. 2019, 245, 600-606. [CrossRef]

27. Browne, M.A.; Dissanayake, A.; Galloway, T.S.; Lowe, D.M.; Thompson, R.C. Ingested microscopic plastic translocates to the circulatory system of the mussel, Mytilus edulis (L.). Environ. Sci. Technol. 2008, 42, 5026-5031. [CrossRef] [PubMed]

28. Boerger, C.M.; Lattin, G.L.; Moore, S.L.; Moore, C.J. Plastic ingestion by planktivorous fishes in the North Pacific Central Gyre. Mar. Pollut. Bull. 2010, 60, 2275-2278. [CrossRef]

29. Lusher, A.L.; McHugh, M.; Thompson, R.C. Occurrence of microplastics in the gastrointestinal tract of pelagic and demersal fish from the English Channel. Mar. Pollut. Bull. 2013, 67, 94-99. [CrossRef]

30. Horton, A.A.; Jürgens, M.D.; Lahive, E.; van Bodegom, P.M.; Vijver, M.G. The influence of exposure and physiology on microplastic ingestion by the freshwater fish Rutilus rutilus (roach) in the River Thames, UK. Environ. Pollut. 2018, 236, 188-194. [CrossRef]

31. Rochman, C.M.; Hoh, E.; Kurobe, T.; Teh, S.J. Ingested plastic transfers hazardous chemicals to fish and induces hepatic stress. Sci. Rep. 2013, 3, 1-7. [CrossRef]

32. Pham, C.K.; Rodríguez, Y.; Dauphin, A.; Carriço, R.; Frias, J.P.G.L.; Vandeperre, F.; Otero, V.; Santos, M.R.; Martins, H.R.; Bolten, A.B.; et al. Plastic ingestion in oceanic-stage loggerhead sea turtles (Caretta caretta) off the North Atlantic subtropical gyre. Mar. Pollut. Bull. 2017, 121, 222-229. [CrossRef]

33. Van Franeker, J.A.; Blaize, C.; Danielsen, J.; Fairclough, K.; Gollan, J.; Guse, N.; Hansen, P.L.; Heubeck, M.; Jensen, J.K.; Le Guillou, G.; et al. Monitoring plastic ingestion by the northern fulmar Fulmarus glacialis in the North Sea. Environ. Pollut. 2011, 159, 2609-2615. [CrossRef]

34. Ryan, P.G.; Connell, A.D.; Gardner, B.D. Marine Pollution Bulletin Plastic Ingestion and PCBs in Seabirds: Is There a Relationship? Mar. Pollut. Bull. 1988, 19, 174-176. [CrossRef]

35. Lavers, J.L.; Bond, A.L. Ingested plastic as a route for trace metals in Laysan Albatross (Phoebastria immutabilis) and Bonin Petrel (Pterodroma hypoleuca) from Midway Atoll. Mar. Pollut. Bull. 2016, 110, 493-500. [CrossRef] [PubMed]

36. Prokić, M.D.; Radovanović, T.B.; Gavrić, J.P.; Faggio, C. Ecotoxicological effects of microplastics: Examination of biomarkers, current state and future perspectives. TrAC-Trends Anal. Chem. 2019, 111, 37-46. [CrossRef]

37. Karami, A.; Groman, D.B.; Wilson, S.P.; Ismail, P.; Neela, V.K. Biomarker responses in zebrafish (Danio rerio) larvae exposed to pristine low-density polyethylene fragments. Environ. Pollut. 2017, 223, 466-475. [CrossRef] [PubMed]

38. Rochman, C.M.; Parnis, J.M.; Browne, M.A.; Serrato, S.; Reiner, E.J.; Robson, M.; Young, T.; Diamond, M.L.; Teh, S.J. Direct and indirect effects of different types of microplastics on freshwater prey (Corbicula fluminea) and their predator (Acipenser transmontanus). PLoS ONE 2017, 12, e0187664. [CrossRef] [PubMed]

39. Qiao, R.; Sheng, C.; Lu, Y.; Zhang, Y.; Ren, H.; Lemos, B. Microplastics induce intestinal inflammation, oxidative stress, and disorders of metabolome and microbiome in zebrafish. Sci. Total Environ. 2019, 662, 246-253. [CrossRef]

40. Zhao, Y.; Bao, Z.; Wan, Z.; Fu, Z.; Jin, Y. Polystyrene microplastic exposure disturbs hepatic glycolipid metabolism at the physiological, biochemical, and transcriptomic levels in adult zebrafish. Sci. Total Environ. 2020, 710, 136279. [CrossRef]

41. Mazurais, D.; Ernande, B.; Quazuguel, P.; Severe, A.; Huelvan, C.; Madec, L.; Mouchel, O.; Soudant, P.; Robbens, J.; Huvet, A.; et al. Evaluation of the impact of polyethylene microbeads ingestion in European sea bass (Dicentrarchus labrax) larvae. Mar. Environ. Res. 2015, 112, 78-85. [CrossRef]

42. Rummel, C.D.; Jahnke, A.; Gorokhova, E.; Kühnel, D.; Schmitt-Jansen, M. Impacts of biofilm formation on the fate and potential effects of microplastic in the aquatic environment. Environ. Sci. Technol. Lett. 2017, 4, 258-267. [CrossRef]

43. Richard, H.; Carpenter, E.J.; Komada, T.; Palmer, P.T.; Rochman, C.M. Biofilm facilitates metal accumulation onto microplastics in estuarine waters. Sci. Total Environ. 2019, 683, 600-608. [CrossRef]

44. Vandenberg, L.N.; Maffini, M.V.; Sonnenschein, C.; Rubin, B.S.; Soto, A.M. Bisphenol-a and the great divide: A review of controversies in the field of endocrine disruption. Endocr. Rev. 2009, 30, 75-95. [CrossRef] [PubMed] 
45. Hahladakis, J.N.; Velis, C.A.; Weber, R.; Iacovidou, E.; Purnell, P. An overview of chemical additives present in plastics: Migration, release, fate and environmental impact during their use, disposal and recycling. J. Hazard. Mater. 2018, 344, 179-199. [CrossRef] [PubMed]

46. McDonald, T.A. A perspective on the potential health risks of PBDEs. Chemosphere 2002, 46, 745-755. [CrossRef]

47. Talsness, C.E. Overview of toxicological aspects of polybrominated diphenyl ethers: A flame-retardant additive in several consumer products. Environ. Res. 2008, 108, 158-167. [CrossRef]

48. Guilhermino, L.; Vieira, L.R.; Ribeiro, D.; Tavares, A.S.; Cardoso, V.; Alves, A.; Almeida, J.M. Uptake and effects of the antimicrobial florfenicol, microplastics and their mixtures on freshwater exotic invasive bivalve Corbicula fluminea. Sci. Total Environ. 2018, 622-623, 1131-1142. [CrossRef]

49. Velzeboer, I.; Kwadijk, C.J.A.F.; Koelmans, A.A. Strong sorption of PCBs to nanoplastics, microplastics, carbon nanotubes, and fullerenes. Environ. Sci. Technol. 2014, 48, 4869-4876. [CrossRef]

50. Rochman, C.M.; Manzano, C.; Hentschel, B.T.; Simonich, S.L.M.; Hoh, E. Polystyrene plastic: A source and sink for polycyclic aromatic hydrocarbons in the marine environment. Environ. Sci. Technol. 2013, 47, 13976-13984. [CrossRef]

51. Pascall, M.A.; Zabik, M.E.; Zabik, M.J.; Hernandez, R.J. Uptake of polychlorinated biphenyls (PCBs) from an aqueous medium by polyethylene, polyvinyl chloride, and polystyrene films. J. Agric. Food Chem. 2005, 53, 164-169. [CrossRef]

52. Rochman, C.M.; Hoh, E.; Hentschel, B.T.; Kaye, S. Long-term field measurement of sorption of organic contaminants to five types of plastic pellets: Implications for plastic marine debris. Environ. Sci. Technol. 2013, 47, 1646-1654. [CrossRef]

53. Hüffer, T.; Hofmann, T. Sorption of non-polar organic compounds by micro-sized plastic particles in aqueous solution. Environ. Pollut. 2016, 214, 194-201. [CrossRef]

54. Teuten, E.L.; Saquing, J.M.; Knappe, D.R.U.; Barlaz, M.A.; Jonsson, S.; Björn, A.; Rowland, S.J.; Thompson, R.C.; Galloway, T.S.; Yamashita, R.; et al. Transport and release of chemicals from plastics to the environment and to wildlife. Philos. Trans. R. Soc. B Biol. Sci. 2009, 364, 2027-2045. [CrossRef] [PubMed]

55. Lohmann, R. Microplastics are not important for the cycling and bioaccumulation of organic pollutants in the oceans-but should microplastics be considered POPs themselves? Integr. Environ. Assess. Manag. 2017, 13, 460-465. [CrossRef] [PubMed]

56. Li, J.; Zhang, K.; Zhang, H. Adsorption of antibiotics on microplastics. Environ. Pollut. 2018, 237, 460-467. [CrossRef]

57. Razanajatovo, R.M.; Ding, J.; Zhang, S.; Jiang, H.; Zou, H. Sorption and desorption of selected pharmaceuticals by polyethylene microplastics. Mar. Pollut. Bull. 2018, 136, 516-523. [CrossRef] [PubMed]

58. Ho, W.K.; Leung, K.S.Y. Sorption and desorption of organic UV filters onto microplastics in single and multi-solute systems. Environ. Pollut. 2019, 254, 113066. [CrossRef] [PubMed]

59. Hartmann, N.B.; Rist, S.; Bodin, J.; Jensen, L.H.S.; Schmidt, S.N.; Mayer, P.; Meibom, A.; Baun, A. Microplastics as vectors for environmental contaminants: Exploring sorption, desorption, and transfer to biota. Integr. Environ. Assess. Manag. 2017, 13, 488-493. [CrossRef] [PubMed]

60. Wardrop, P.; Shimeta, J.; Nugegoda, D.; Morrison, P.D.; Miranda, A.; Tang, M.; Clarke, B.O. Chemical Pollutants Sorbed to Ingested Microbeads from Personal Care Products Accumulate in Fish. Environ. Sci. Technol. 2016, 50, 4037-4044. [CrossRef]

61. Ma, Y.; Huang, A.; Cao, S.; Sun, F.; Wang, L.; Guo, H.; Ji, R. Effects of nanoplastics and microplastics on toxicity, bioaccumulation, and environmental fate of phenanthrene in fresh water. Environ. Pollut. 2016, 219, 166-173. [CrossRef]

62. Bakir, A.; Rowland, S.J.; Thompson, R.C. Enhanced desorption of persistent organic pollutants from microplastics under simulated physiological conditions. Environ. Pollut. 2014, 185, 16-23. [CrossRef]

63. Mohamed Nor, N.H.; Koelmans, A.A. Transfer of PCBs from Microplastics under Simulated Gut Fluid Conditions Is Biphasic and Reversible. Environ. Sci. Technol. 2019, 53, 1874-1883. [CrossRef]

64. Koelmans, A.A.; Besseling, E.; Wegner, A.; Foekema, E.M. Plastic as a carrier of POPs to aquatic organisms: A model analysis. Environ. Sci. Technol. 2013, 47, 7812-7820. [CrossRef]

65. Wang, J.; Coffin, S.; Sun, C.; Schlenk, D.; Gan, J. Negligible effects of microplastics on animal fitness and HOC bioaccumulation in earthworm Eisenia fetida in soil. Environ. Pollut. 2019, 249, 776-784. [CrossRef] 
66. Herzke, D.; Anker-Nilssen, T.; Nøst, T.H.; Götsch, A.; Christensen-Dalsgaard, S.; Langset, M.; Fangel, K.; Koelmans, A.A. Negligible Impact of Ingested Microplastics on Tissue Concentrations of Persistent Organic Pollutants in Northern Fulmars off Coastal Norway. Environ. Sci. Technol. 2016, 50, 1924-1933. [CrossRef] [PubMed]

67. Eriksen, M.; Lebreton, L.C.M.; Carson, H.S.; Thiel, M.; Moore, C.J.; Borerro, J.C.; Galgani, F.; Ryan, P.G.; Reisser, J. Plastic Pollution in the World's Oceans: More than 5 Trillion Plastic Pieces Weighing over 250,000 Tons Afloat at Sea. PLoS ONE 2014, 9, e0111913. [CrossRef] [PubMed]

68. Hanvey, J.S.; Lewis, P.J.; Lavers, J.L.; Crosbie, N.D.; Pozo, K.; Clarke, B.O. A review of analytical techniques for quantifying microplastics in sediments. Anal. Methods 2017, 9, 1369-1383. [CrossRef]

69. Chen, G.; Feng, Q.; Wang, J. Mini-review of microplastics in the atmosphere and their risks to humans. Sci. Total Environ. 2020, 703, 135504. [CrossRef] [PubMed]

70. Wang, W.; Ge, J.; Yu, X.; Li, H. Environmental fate and impacts of microplastics in soil ecosystems: Progress and perspective. Sci. Total Environ. 2020, 708, 134841. [CrossRef]

71. Barbosa, F.; Adeyemi, J.A.; Bocato, M.Z.; Comas, A.; Campiglia, A. A critical viewpoint on current issues, limitations, and future research needs on micro- and nanoplastic studies: From the detection to the toxicological assessment. Environ. Res. 2020, 182, 109089. [CrossRef]

72. Tourinho, P.S.; Kočí, V.; Loureiro, S.; van Gestel, C.A.M. Partitioning of chemical contaminants to microplastics: Sorption mechanisms, environmental distribution and effects on toxicity and bioaccumulation. Environ. Pollut. 2019, 252, 1246-1256. [CrossRef]

73. Fred-Ahmadu, O.H.; Bhagwat, G.; Oluyoye, I.; Benson, N.U.; Ayejuyo, O.O.; Palanisami, T. Interaction of chemical contaminants with microplastics: Principles and perspectives. Sci. Total Environ. 2020, 706, 135978. [CrossRef]

74. Rodrigues, J.P.; Duarte, A.C.; Santos-Echeandía, J.; Rocha-Santos, T. Significance of interactions between microplastics and POPs in the marine environment: A critical overview. TrAC—Trends Anal. Chem. 2019, 111, 252-260. [CrossRef]

75. Li, C.; Busquets, R.; Campos, L.C. Assessment of microplastics in freshwater systems: A review. Sci. Total Environ. 2020, 707, 135578. [CrossRef] [PubMed]

76. Liu, P.; Zhan, X.; Wu, X.; Li, J.; Wang, H.; Gao, S. Effect of weathering on environmental behavior of microplastics: Properties, sorption and potential risks. Chemosphere 2020, 242, 125193. [CrossRef] [PubMed]

77. Ziccardi, L.M.; Edgington, A.; Hentz, K.; Kulacki, K.J.; Kane Driscoll, S. Microplastics as vectors for bioaccumulation of hydrophobic organic chemicals in the marine environment: A state-of-the-science review. Environ. Toxicol. Chem. 2016, 35, 1667-1676. [CrossRef]

78. Bakir, A.; Rowland, S.J.; Thompson, R.C. Competitive sorption of persistent organic pollutants onto microplastics in the marine environment. Mar. Pollut. Bull. 2012, 64, 2782-2789. [CrossRef]

79. Endo, S.; Koelmans, A.A. Sorption of hydrophobic organic compounds in marine environments: Equilibrium. In Hazardous Chemicals Associated with Plastics in the Marine Environment; Springer: Berlin/Heidelberg, Germany, 2019; pp. 185-204. ISBN 9783319955667.

80. Fang, S.; Yu, W.; Li, C.; Liu, Y.; Qiu, J.; Kong, F. Adsorption behavior of three triazole fungicides on polystyrene microplastics. Sci. Total Environ. 2019, 691, 1119-1126. [CrossRef]

81. Xu, P.; Ge, W.; Chai, C.; Zhang, Y.; Jiang, T.; Xia, B. Sorption of polybrominated diphenyl ethers by microplastics. Mar. Pollut. Bull. 2019, 145, 260-269. [CrossRef]

82. Holmes, L.A.; Turner, A.; Thompson, R.C. Interactions between trace metals and plastic production pellets under estuarine conditions. Mar. Chem. 2014, 167, 25-32. [CrossRef]

83. Wang, F.; Wong, C.S.; Chen, D.; Lu, X.; Wang, F.; Zeng, E.Y. Interaction of toxic chemicals with microplastics: A critical review. Water Res. 2018, 139, 208-219. [CrossRef]

84. Seidensticker, S.; Grathwohl, P.; Lamprecht, J.; Zarfl, C. A combined experimental and modeling study to evaluate $\mathrm{pH}$-dependent sorption of polar and non-polar compounds to polyethylene and polystyrene microplastics. Environ. Sci. Eur. 2018, 30, 1-12. [CrossRef]

85. Brennecke, D.; Duarte, B.; Paiva, F.; Caçador, I.; Canning-Clode, J. Microplastics as vector for heavy metal contamination from the marine environment. Estuar. Coast. Shelf Sci. 2016, 178, 189-195. [CrossRef]

86. Mato, Y.; Isobe, T.; Takada, H.; Kanehiro, H.; Ohtake, C.; Kaminuma, T. Plastic resin pellets as a transport medium for toxic chemicals in the marine environment. Environ. Sci. Technol. 2001, 35, 318-324. [CrossRef] [PubMed] 
87. Ogata, Y.; Takada, H.; Mizukawa, K.; Hirai, H.; Iwasa, S.; Endo, S.; Mato, Y.; Saha, M.; Okuda, K.; Nakashima, A.; et al. International Pellet Watch: Global monitoring of persistent organic pollutants (POPs) in coastal waters. 1. Initial phase data on PCBs, DDTs, and HCHs. Mar. Pollut. Bull. 2009, 58, 1437-1446. [CrossRef] [PubMed]

88. Chen, Q.; Zhang, H.; Allgeier, A.; Zhou, Q.; Ouellet, J.D.; Crawford, S.E.; Luo, Y.; Yang, Y.; Shi, H.; Hollert, H. Marine microplastics bound dioxin-like chemicals: Model explanation and risk assessment. J. Hazard. Mater. 2019, 364, 82-90. [CrossRef] [PubMed]

89. Antunes, J.C.; Frias, J.G.L.; Micaelo, A.C.; Sobral, P. Resin pellets from beaches of the Portuguese coast and adsorbed persistent organic pollutants. Estuar. Coast. Shelf Sci. 2013, 130, 62-69. [CrossRef]

90. Van, A.; Rochman, C.M.; Flores, E.M.; Hill, K.L.; Vargas, E.; Vargas, S.A.; Hoh, E. Persistent organic pollutants in plastic marine debris found on beaches in San Diego, California. Chemosphere 2012, 86, 258-263. [CrossRef]

91. Hüffer, T.; Weniger, A.K.; Hofmann, T. Sorption of organic compounds by aged polystyrene microplastic particles. Environ. Pollut. 2018, 236, 218-225. [CrossRef]

92. Fu, D.; Zhang, Q.; Fan, Z.; Qi, H.; Wang, Z.; Peng, L. Aged microplastics polyvinyl chloride interact with copper and cause oxidative stress towards microalgae Chlorella vulgaris. Aquat. Toxicol. 2019, 216, 105319. [CrossRef]

93. Wang, Q.; Zhang, Y.; Wangjin, X.; Wang, Y.; Meng, G.; Chen, Y. The adsorption behavior of metals in aqueous solution by microplastics effected by UV radiation. J. Environ. Sci. (China) 2020, 87, 272-280. [CrossRef]

94. Johansen, M.P.; Cresswell, T.; Davis, J.; Howard, D.L.; Howell, N.R.; Prentice, E. Biofilm-enhanced adsorption of strong and weak cations onto different microplastic sample types: Use of spectroscopy, microscopy and radiotracer methods. Water Res. 2019, 158, 392-400. [CrossRef]

95. Van Den Berg, M.; Birnbaum, L.; Bosveld, A.T.C.; Brunström, B.; Cook, P.; Feeley, M.; Giesy, J.P.; Hanberg, A.; Hasegawa, R.; Kennedy, S.W.; et al. Toxic equivalency factors (TEFs) for PCBs, PCDDs, PCDFs for humans and wildlife. Environ. Health Perspect. 1998, 106, 775-792. [CrossRef] [PubMed]

96. Wang, F.; Shih, K.M.; Li, X.Y. The partition behavior of perfluorooctanesulfonate (PFOS) and perfluorooctanesulfonamide (FOSA) on microplastics. Chemosphere 2015, 119, 841-847. [CrossRef] [PubMed]

97. Yu, Y.; Ma, R.; Qu, H.; Zuo, Y.; Yu, Z.; Hu, G.; Li, Z.; Chen, H.; Lin, B.; Wang, B.; et al. Enhanced adsorption of tetrabromobisphenol a (TBBPA) on cosmetic-derived plastic microbeads and combined effects on zebrafish. Chemosphere 2020, 248, 126067. [CrossRef] [PubMed]

98. Elizalde-Velázquez, A.; Subbiah, S.; Anderson, T.A.; Green, M.J.; Zhao, X.; Cañas-Carrell, J.E. Sorption of three common nonsteroidal anti-inflammatory drugs (NSAIDs) to microplastics. Sci. Total Environ. 2020, 715, 136974. [CrossRef] [PubMed]

99. Guo, X.; Chen, C.; Wang, J. Sorption of sulfamethoxazole onto six types of microplastics. Chemosphere 2019, 228, 300-308. [CrossRef] [PubMed]

100. Shen, X.C.; Li, D.C.; Sima, X.F.; Cheng, H.Y.; Jiang, H. The effects of environmental conditions on the enrichment of antibiotics on microplastics in simulated natural water column. Environ. Res. 2018, 166, 377-383. [CrossRef]

101. Zhang, H.; Wang, J.; Zhou, B.; Zhou, Y.; Dai, Z.; Zhou, Q.; Chriestie, P.; Luo, Y. Enhanced adsorption of oxytetracycline to weathered microplastic polystyrene: Kinetics, isotherms and influencing factors. Environ. Pollut. 2018, 243, 1550-1557. [CrossRef]

102. Qiao, R.; Lu, K.; Deng, Y.; Ren, H.; Zhang, Y. Combined effects of polystyrene microplastics and natural organic matter on the accumulation and toxicity of copper in zebrafish. Sci. Total Environ. 2019, 682, 128-137. [CrossRef]

103. Wu, C.; Zhang, K.; Huang, X.; Liu, J. Sorption of pharmaceuticals and personal care products to polyethylene debris. Environ. Sci. Pollut. Res. 2016, 23, 8819-8826. [CrossRef]

104. Gouin, T.; Roche, N.; Lohmann, R.; Hodges, G. A thermodynamic approach for assessing the environmental exposure of chemicals absorbed to microplastic. Environ. Sci. Technol. 2011, 45, 1466-1472. [CrossRef] [PubMed]

105. Granby, K.; Rainieri, S.; Rasmussen, R.R.; Kotterman, M.J.J.; Sloth, J.J.; Cederberg, T.L.; Barranco, A.; Marques, A.; Larsen, B.K. The influence of microplastics and halogenated contaminants in feed on toxicokinetics and gene expression in European seabass (Dicentrarchus labrax). Environ. Res. 2018, 164, 430-443. [CrossRef] [PubMed] 
106. Rummel, C.D.; Adolfsson-Erici, M.; Jahnke, A.; MacLeod, M. No measurable "cleaning" of polychlorinated biphenyls from Rainbow Trout in a 9 week depuration study with dietary exposure to $40 \%$ polyethylene microspheres. Environ. Sci. Process. Impacts 2016, 18, 788-795. [CrossRef] [PubMed]

107. Avio, C.G.; Gorbi, S.; Milan, M.; Benedetti, M.; Fattorini, D.; D’Errico, G.; Pauletto, M.; Bargelloni, L.; Regoli, F. Pollutants bioavailability and toxicological risk from microplastics to marine mussels. Environ. Pollut. 2015, 198, 211-222. [CrossRef] [PubMed]

108. Devriese, L.I.; De Witte, B.; Vethaak, A.D.; Hostens, K.; Leslie, H.A. Bioaccumulation of PCBs from microplastics in Norway lobster (Nephrops norvegicus): An experimental study. Chemosphere 2017, 186, 10-16. [CrossRef]

109. Zhang, S.; Ding, J.; Razanajatovo, R.M.; Jiang, H.; Zou, H.; Zhu, W. Interactive effects of polystyrene microplastics and roxithromycin on bioaccumulation and biochemical status in the freshwater fish red tilapia (Oreochromis niloticus). Sci. Total Environ. 2019, 648, 1431-1439. [CrossRef]

110. Qu, H.; Ma, R.; Wang, B.; Yang, J.; Duan, L.; Yu, G. Enantiospecific toxicity, distribution and bioaccumulation of chiral antidepressant venlafaxine and its metabolite in loach (Misgurnus anguillicaudatus) co-exposed to microplastic and the drugs. J. Hazard. Mater. 2019, 370, 203-211. [CrossRef]

111. Beiras, R.; Muniategui-Lorenzo, S.; Rodil, R.; Tato, T.; Montes, R.; López-Ibáñez, S.; Concha-Graña, E.; Campoy-López, P.; Salgueiro-González, N.; Quintana, J.B. Polyethylene microplastics do not increase bioaccumulation or toxicity of nonylphenol and 4-MBC to marine zooplankton. Sci. Total Environ. 2019, 692, 1-9. [CrossRef]

112. Sala, B.; Giménez, J.; de Stephanis, R.; Barceló, D.; Eljarrat, E. First determination of high levels of organophosphorus flame retardants and plasticizers in dolphins from Southern European waters. Environ. Res. 2019, 172, 289-295. [CrossRef]

113. Chen, Q.; Yin, D.; Jia, Y.; Schiwy, S.; Legradi, J.; Yang, S.; Hollert, H. Enhanced uptake of BPA in the presence of nanoplastics can lead to neurotoxic effects in adult zebrafish. Sci. Total Environ. 2017, 609, 1312-1321. [CrossRef]

114. Wania, F.; Mackay, D. Tracking the distribution of persistent organic pollutants. Environ. Sci. Technol. 1996, 30, 390-396. [CrossRef]

115. Khan, F.R.; Syberg, K.; Shashoua, Y.; Bury, N.R. Influence of polyethylene microplastic beads on the uptake and localization of silver in zebrafish (Danio rerio). Environ. Pollut. 2015, 206, 73-79. [CrossRef] [PubMed]

116. Rochman, C.M.; Lewison, R.L.; Eriksen, M.; Allen, H.; Cook, A.M.; Teh, S.J. Polybrominated diphenyl ethers (PBDEs) in fish tissue may be an indicator of plastic contamination in marine habitats. Sci. Total Environ. 2014, 476, 622-633. [CrossRef] [PubMed]

117. Gassel, M.; Rochman, C.M. The complex issue of chemicals and microplastic pollution: A case study in North Pacific lanternfish. Environ. Pollut. 2019, 248, 1000-1009. [CrossRef] [PubMed]

118. Tanaka, K.; Takada, H.; Yamashita, R.; Mizukawa, K.; Fukuwaka, M.A.; Watanuki, Y. Accumulation of plastic-derived chemicals in tissues of seabirds ingesting marine plastics. Mar. Pollut. Bull. 2013, 69, $219-222$. [CrossRef]

119. Davarpanah, E.; Guilhermino, L. Single and combined effects of microplastics and copper on the population growth of the marine microalgae Tetraselmis chuii. Estuar. Coast. Shelf Sci. 2015, 167, 269-275. [CrossRef]

120. Kim, D.; Chae, Y.; An, Y.J. Mixture Toxicity of Nickel and Microplastics with Different Functional Groups on Daphnia magna. Environ. Sci. Technol. 2017, 51, 12852-12858. [CrossRef]

121. Luís, L.G.; Ferreira, P.; Fonte, E.; Oliveira, M.; Guilhermino, L. Does the presence of microplastics influence the acute toxicity of chromium(VI) to early juveniles of the common goby (Pomatoschistus microps)? A study with juveniles from two wild estuarine populations. Aquat. Toxicol. 2015, 164, 163-174. [CrossRef]

122. Wen, B.; Jin, S.R.; Chen, Z.Z.; Gao, J.Z.; Liu, Y.N.; Liu, J.H.; Feng, X.S. Single and combined effects of microplastics and cadmium on the cadmium accumulation, antioxidant defence and innate immunity of the discus fish (Symphysodon aequifasciatus). Environ. Pollut. 2018, 243, 462-471. [CrossRef]

123. Lu, K.; Qiao, R.; An, H.; Zhang, Y. Influence of microplastics on the accumulation and chronic toxic effects of cadmium in zebrafish (Danio rerio). Chemosphere 2018, 202, 514-520. [CrossRef]

124. Barboza, L.G.A.; Vieira, L.R.; Branco, V.; Figueiredo, N.; Carvalho, F.; Carvalho, C.; Guilhermino, L. Microplastics cause neurotoxicity, oxidative damage and energy-related changes and interact with the bioaccumulation of mercury in the European seabass, Dicentrarchus labrax (Linnaeus, 1758). Aquat. Toxicol. 2018, 195, 49-57. [CrossRef] 
125. Oliveira, P.; Barboza, L.G.A.; Branco, V.; Figueiredo, N.; Carvalho, C.; Guilhermino, L. Effects of microplastics and mercury in the freshwater bivalve Corbicula fluminea (Müller, 1774): Filtration rate, biochemical biomarkers and mercury bioconcentration. Ecotoxicol. Environ. Saf. 2018, 164, 155-163. [CrossRef]

126. Guven, O.; Bach, L.; Munk, P.; Dinh, K.V.; Mariani, P.; Nielsen, T.G. Microplastic does not magnify the acute effect of PAH pyrene on predatory performance of a tropical fish (Lates calcarifer). Aquat. Toxicol. 2018, 198, 287-293. [CrossRef]

127. Rochman, C.M.; Kurobe, T.; Flores, I.; Teh, S.J. Early warning signs of endocrine disruption in adult fish from the ingestion of polyethylene with and without sorbed chemical pollutants from the marine environment. Sci. Total Environ. 2014, 493, 656-661. [CrossRef]

128. Phuong, N.N.; Zalouk-Vergnoux, A.; Poirier, L.; Kamari, A.; Châtel, A.; Mouneyrac, C.; Lagarde, F. Is there any consistency between the microplastics found in the field and those used in laboratory experiments? Environ. Pollut. 2016, 211, 111-123. [CrossRef]

129. Schirinzi, G.F.; Pérez-Pomeda, I.; Sanchís, J.; Rossini, C.; Farré, M.; Barceló, D. Cytotoxic effects of commonly used nanomaterials and microplastics on cerebral and epithelial human cells. Environ. Res. 2017, 159, 579-587. [CrossRef]

130. Oliveira, M.; Ribeiro, A.; Hylland, K.; Guilhermino, L. Single and combined effects of microplastics and pyrene on juveniles ( $0+$ group) of the common goby Pomatoschistus microps (Teleostei, Gobiidae). Ecol. Indic. 2013, 34, 641-647. [CrossRef]

131. Magara, G.; Elia, A.C.; Syberg, K.; Khan, F.R. Single contaminant and combined exposures of polyethylene microplastics and fluoranthene: Accumulation and oxidative stress response in the blue mussel, Mytilus edulis. J. Toxicol. Environ. Health Part A Curr. Issues 2018, 81, 761-773. [CrossRef]

132. Paul-Pont, I.; Lacroix, C.; González Fernández, C.; Hégaret, H.; Lambert, C.; Le Goïc, N.; Frère, L.; Cassone, A.L.; Sussarellu, R.; Fabioux, C.; et al. Exposure of marine mussels Mytilus spp. to polystyrene microplastics: Toxicity and influence on fluoranthene bioaccumulation. Environ. Pollut. 2016, 216, 724-737. [CrossRef]

133. Pittura, L.; Avio, C.G.; Giuliani, M.E.; D’Errico, G.; Keiter, S.H.; Cormier, B.; Gorbi, S.; Regoli, F. Microplastics as vehicles of environmental PAHs to marine organisms: Combined chemical and physical hazards to the mediterranean mussels, Mytilus galloprovincialis. Front. Mar. Sci. 2018, 5, 103. [CrossRef]

134. Kleinteich, J.; Seidensticker, S.; Marggrander, N.; Zarf, C. Microplastics reduce short-term effects of environmental contaminants. part II: Polyethylene particles decrease the effect of polycyclic aromatic hydrocarbons on microorganisms. Int. J. Environ. Res. Public Health 2018, 15, 287. [CrossRef]

135. Karami, A.; Romano, N.; Galloway, T.; Hamzah, H. Virgin microplastics cause toxicity and modulate the impacts of phenanthrene on biomarker responses in African catfish (Clarias gariepinus). Environ. Res. 2016, 151, 58-70. [CrossRef]

136. Rainieri, S.; Conlledo, N.; Larsen, B.K.; Granby, K.; Barranco, A. Combined effects of microplastics and chemical contaminants on the organ toxicity of zebrafish (Danio rerio). Environ. Res. 2018, 162, 135-143. [CrossRef] [PubMed]

137. Bellas, J.; Gil, I. Polyethylene microplastics increase the toxicity of chlorpyrifos to the marine copepod Acartia tonsa. Environ. Pollut. 2020, 260. [CrossRef] [PubMed]

138. Garrido, S.; Linares, M.; Campillo, J.A.; Albentosa, M. Effect of microplastics on the toxicity of chlorpyrifos to the microalgae Isochrysis galbana, clone t-ISO. Ecotoxicol. Environ. Saf. 2019, 173, 103-109. [CrossRef]

139. Yi, X.; Chi, T.; Li, Z.; Wang, J.; Yu, M.; Wu, M.; Zhou, H. Combined effect of polystyrene plastics and triphenyltin chloride on the green algae Chlorella pyrenoidosa. Environ. Sci. Pollut. Res. 2019, 26, 15011-15018. [CrossRef]

140. Ziajahromi, S.; Kumar, A.; Neale, P.A.; Leusch, F.D.L. Effects of polyethylene microplastics on the acute toxicity of a synthetic pyrethroid to midge larvae (Chironomus tepperi) in synthetic and river water. Sci. Total Environ. 2019, 671, 971-975. [CrossRef]

141. Zocchi, M.; Sommaruga, R. Microplastics modify the toxicity of glyphosate on Daphnia magna. Sci. Total Environ. 2019, 697, 1-7. [CrossRef]

142. Horton, A.A.; Vijver, M.G.; Lahive, E.; Spurgeon, D.J.; Svendsen, C.; Heutink, R.; van Bodegom, P.M.; Baas, J. Acute toxicity of organic pesticides to Daphnia magna is unchanged by co-exposure to polystyrene microplastics. Ecotoxicol. Environ. Saf. 2018, 166, 26-34. [CrossRef] 
143. Fonte, E.; Ferreira, P.; Guilhermino, L. Temperature rise and microplastics interact with the toxicity of the antibiotic cefalexin to juveniles of the common goby (Pomatoschistus microps): Post-exposure predatory behaviour, acetylcholinesterase activity and lipid peroxidation. Aquat. Toxicol. 2016, 180, 173-185. [CrossRef]

144. Syberg, K.; Nielsen, A.; Khan, F.R.; Banta, G.T.; Palmqvist, A.; Jepsen, P.M. Microplastic potentiates triclosan toxicity to the marine copepod Acartia tonsa (Dana). J. Toxicol. Environ. Health-Part A Curr. Issues 2017, 80, 1369-1371. [CrossRef]

145. Prata, J.C.; Lavorante, B.R.; Maria da Conceição, B.S.M.; Guilhermino, L. Influence of microplastics on the toxicity of the pharmaceuticals procainamide and doxycycline on the marine microalgae Tetraselmis chuii. Aquat. Toxicol. 2018, 197, 143-152. [CrossRef] [PubMed]

146. Shi, W.; Han, Y.; Sun, S.; Tang, Y.; Zhou, W.; Du, X.; Liu, G. Immunotoxicities of microplastics and sertraline, alone and in combination, to a bivalve species: Size-dependent interaction and potential toxication mechanism. J. Hazard. Mater. 2020, 396, 122603. [CrossRef] [PubMed]

147. Beiras, R.; Tato, T. Microplastics do not increase toxicity of a hydrophobic organic chemical to marine plankton. Mar. Pollut. Bull. 2019, 138, 58-62. [CrossRef]

148. Li, Z.; Yi, X.; Zhou, H.; Chi, T.; Li, W.; Yang, K. Combined effect of polystyrene microplastics and dibutyl phthalate on the microalgae Chlorella pyrenoidosa. Environ. Pollut. 2020, 257. [CrossRef]

149. Schrank, I.; Trotter, B.; Dummert, J.; Scholz-Böttcher, B.M.; Löder, M.G.J.; Laforsch, C. Effects of microplastic particles and leaching additive on the life history and morphology of Daphnia magna. Environ. Pollut. 2019, 255, 113233. [CrossRef]

150. Koh, E.J.; Hwang, S.Y. Multi-omics approaches for understanding environmental exposure and human health. Mol. Cell. Toxicol. 2019, 15, 1-7. [CrossRef]

(C) 2020 by the authors. Licensee MDPI, Basel, Switzerland. This article is an open access article distributed under the terms and conditions of the Creative Commons Attribution (CC BY) license (http://creativecommons.org/licenses/by/4.0/). 